\title{
Inclusion Complex of Zerumbone with Hydroxypropyl- $\beta$-Cyclodextrin Induces Apoptosis in Liver Hepatocellular HepG2 Cells via Caspase 8/BID Cleavage Switch and Modulating Bcl2/Bax Ratio
}

\author{
Nabilah Muhammad Nadzri, ${ }^{1}$ Ahmad Bustamam Abdul, ${ }^{1}$ Mohd Aspollah Sukari, ${ }^{2}$ \\ Siddig Ibrahim Abdelwahab,, ${ }^{3,4}$ Eltayeb E. M. Eid, ${ }^{1,5}$ Syam Mohan, ${ }^{3}$ Behnam \\ Kamalidehghan, ${ }^{3}$ Theebaa Anasamy, ${ }^{1}$ Kuan Beng Ng, ${ }^{1}$ Suvitha Syam, ${ }^{1}$ Ismail Adam Arbab, ${ }^{1}$ \\ Heshu Sulaiman Rahman, ${ }^{1,6}$ and Hapipah Mohd $\mathrm{Ali}^{7}$ \\ ${ }^{1}$ UPM-MAKNA Cancer Research Laboratory, Institute of Bioscience, University Putra Malaysia (UPM), Serdang, \\ 43400 Selangor, Malaysia \\ ${ }^{2}$ Department of Chemistry, Faculty of Science, University Putra Malaysia (UPM), Serdang, \\ 43400 Selangor, Malaysia \\ ${ }^{3}$ Department of Pharmacy, Faculty of Medicine Building, University of Malaya, 50603 Kuala Lumpur, Malaysia \\ ${ }^{4}$ Medical Research Center, Faculty of Medicine, Jazan University, P.O. Box 114, Jazan 45142, Saudi Arabia \\ ${ }^{5}$ College of Pharmacy, Qassim University, P.O. Box 2055, Buraydah 6800, Saudi Arabia \\ ${ }^{6}$ Department of Microbiology and Pathology, Faculty of Veterinary Medicine, University Putra Malaysia (UPM), Serdang, \\ 43400 Selangor, Malaysia \\ ${ }^{7}$ Department of Chemistry, Faculty of Science, University of Malaya, 50603 Kuala Lumpur, Malaysia
}

Correspondence should be addressed to Ahmad Bustamam Abdul; ahmadbstmm@yahoo.com

Received 10 January 2013; Accepted 3 April 2013

Academic Editor: Gail B. Mahady

Copyright (c) 2013 Nabilah Muhammad Nadzri et al. This is an open access article distributed under the Creative Commons Attribution License, which permits unrestricted use, distribution, and reproduction in any medium, provided the original work is properly cited.

\begin{abstract}
Zerumbone (ZER) isolated from Zingiber zerumbet was previously encapsulated with hydroxypropyl- $\beta$-cyclodextrin (HP $\beta$ CD) to enhance ZER's solubility in water, thus making it highly tolerable in the human body. The anticancer effects of this new ZER$\mathrm{HP} \beta \mathrm{CD}$ inclusion complex via apoptosis cell death were assessed in this study for the first time in liver hepatocellular cells, HepG2. Apoptosis was ascertained by morphological study, nuclear stain, and sub-G1 cell population accumulation with G2/M arrest. Further investigations showed the release of cytochrome $\mathrm{c}$ and loss of mitochondrial membrane potential, proving mitochondrial dysfunction upon the ZER-HP $\beta$ CD treatment as well as modulating proapoptotic and anti-apototic Bcl-2 family members. A significant increase in caspase $3 / 7$, caspase 9 , and caspase 8 was detected with the depletion of BID cleaved by caspase 8 . Collectively, these results prove that a highly soluble inclusion complex of ZER-HP $\beta$ CD could be a promising anticancer agent for the treatment of hepatocellular carcinoma in humans.
\end{abstract}

\section{Introduction}

The use of plants as the preferential treatment for cancer has been known for centuries. To date, about 3000 plant species have been identified as possessing anticancer properties. This piece of information is later utilized and investigated by scientists in search for better compounds to act as anticancer agent [1]. One of the most important benefits of using these plants for health purposes is the availability of anticancer agents useful for treatments [2]. This is proven by the fact that more than 60 types of clinical chemotherapy drugs used as anticancer agents are plant derived. Amongst this, a number 
of new, promising anticancer agents in clinical drug development based on selective activity against cancer-related molecular targets include flavopiridol and combretastin-A4phosphate, while other anticancer agents which failed in earlier clinical studies have stimulated renewed interest [1].

Zingiber zerumbet is a member of the family Zingiberaceae. Other plants that belong to this family include Zingiber cassumunar and Zingiber officinale [3]. The plant is also known as lempoyang in Malaysia, Ghatian and Yaiimu in India, and Jangli adha in Bangladesh [4-6]. It can be found in the moist forest, beach thickets and mangrove margin. Z. Zerumbet extracts have been used traditionally for treating fever, headaches, asthma, indigestion, diarrhea, severe sprains, inflammation, constipation, and toothache, while the Malays use the rhizomes extract to cure edema and worm infestation in children [7, 8]. It was found that the oils obtained from the rhizomes were rich in zerumbone $(37 \%)$, $\alpha$-humulene (14.4\%), and camphene (13.8\%) [9].

Zerumbone (ZER) is a crystalline monocyclic sesquiterpene isolated from the rhizomes of $Z$. zerumbet. This bioactive component has a unique structure consisting of a crossconjugated ketone in an 11-membered ring responsible for its entire biological activities (Figure 1). ZER was previously reported to produce cytotoxicity through apoptosis in various cancers including skin tumor, colon and lung carcinogenesis, hepatocarcinogenesis, leukemic cancer, and cervical intraepithelial neoplasia [10-14].

Hydroxypropyl- $\beta$-cyclodextrin $(\mathrm{HP} \beta \mathrm{CD})$ is a cyclodextrin derivative that is used widely in drug encapsulation due to its inclusion ability as well as its high water solubility (Figure 2). $\mathrm{HP} \beta \mathrm{CD}$ is well tolerated by the human body both by intravenous and oral administrations. Previously, we investigated the inclusion complex between ZER and HP $\beta C D$ and its physical characterizations. The study provided evidence that ZER penetrates completely into the cavity of $\mathrm{HP} \beta \mathrm{CD}$, allowing the solubility of ZER to be enhanced with $>30$ fold after complexation. The study further showed that $\mathrm{HP} \beta \mathrm{CD}$ is a suitable encapsular capable of forming a thermodynamically stable complex with ZER for the intended delivery of ZER as an anticancer [15]. Hence, this study further warrants the importance of ZER-encapsulated HP $\beta C D$ as a promising biopharmaceutical drug, which encourages the current study to further investigate the antiproliferative effects of the new ZER-HP $\beta C D$ inclusion complex against liver hepatocellular cells, HepG2, as a potential anticancer. This is the first documented report of ZER-HP $\beta C D$ inclusion complex as an anticancer in HepG2 cells, together with its preliminary investigations of probable molecular mechanism in apoptosis induction.

\section{Materials and Methods}

2.1. Cell Lines and Reagents. HepG2, HeLa, MCF-7, MDAMB-231, CEMss and WRL-68 cells were obtained from American Type Culture Collection (Rockville, MD, USA) and cultured in RPMI1640 (PAA, Germany) media supplemented with $10 \%$ fetal bovine serum (FBS) (PAA, Germany) and 1\% $100 \mathrm{IU}$ penicillin and $100 \mu \mathrm{g} / \mathrm{mL}$ streptomycin (Sigma, USA).

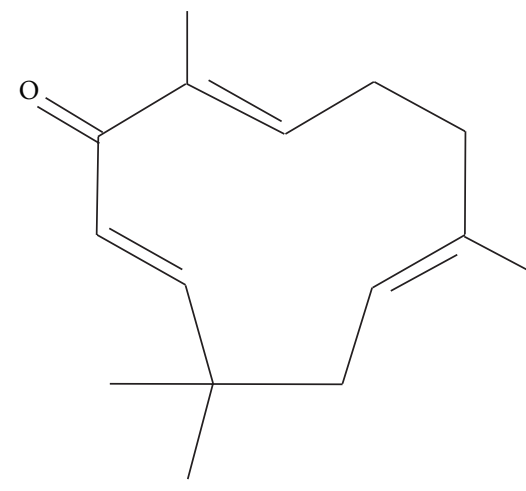

FIGURE 1: Molecular structure of Zerumbone (2,6,10-humulatrien1-one).

Cultures were maintained in a humidified incubator at $37^{\circ} \mathrm{C}$ in an atmosphere of $5 \% \mathrm{CO}_{2}$.

2.2. Inclusion Complex of ZER with HP $\beta C D$. The inclusion complex of ZER with HP $\beta C D$ was obtained from the UPMMAKNA Cancer Research Laboratory, University Putra Malaysia. Briefly, the thermodynamic parameters $(\Delta H, \Delta S$, $\Delta G$ ) for the formation of the complex were obtained from the van't Hoff equation. ZER complex with $\mathrm{HP} \beta C D$ was characterized by differential scanning calorimetry (DSC), X-ray diffractometry (XRD), Fourier transform infrared spectroscopy (FT-IR), Transmission Emission Microscopy (TEM), and molecular modelling using PM6. Calculations show that ZER penetrates completely into the cavity of $\mathrm{HP} \beta \mathrm{CD}[15]$.

2.3. Cytotoxicity Assay. The cytotoxicity profiles of the ZER-HP $\beta C D$ inclusion complex were assessed using 3[4,5-dimethylthiazol-2-yl]-2,5-diphenyltetrazolium bromide (MTT) microculture tetrazolium viability assay as previously described by Mosmann (1983) with slight modifications [16]. Briefly, cells were seeded in 96-well microplates at a density of $2 \times 10^{5}$ cells $\mathrm{mL}^{-1}$. After a 24 -hour incubation, the cells were treated at various concentrations of ZER-HP $\beta C D$ inclusion complex $\left(1.563,3.125,6.25,12.5,25\right.$, and $\left.50 \mu \mathrm{g} \mathrm{mL}^{-1}\right)$ for $72 \mathrm{~h}$. After a 68 -hour incubation, $20 \mu \mathrm{L}$ of MTT solution $\left(5 \mathrm{mg} \mathrm{mL}^{-1}\right)$ (Amresco, USA) was added into each well and the plate was then incubated for $4 \mathrm{~h}$. Subsequently, the media was removed and the formed formazan crystals were dissolved with $100 \mu \mathrm{L}$ of DMSO (Sigma, USA). The absorbance was measured at wavelength of $595 \mathrm{~nm}$ using a microtiter plate reader (Tecan Sunrise basic, Austria). The percentage of cellular viability was calculated with appropriate controls taken into account. The concentration which inhibits $50 \%$ of cellular growth $\left(\mathrm{IC}_{50}\right.$ value) was determined. Three independent experiments performed in triplicates were used for the calculations and statistical analysis.

2.4. Morphological Evaluation by Phase Contrast Inverted Microscopy. Treatment was carried out in $25 \mathrm{~mL}$ culture flask. HepG2 cells were plated at concentration of $2 \times 10^{5}$ cells $\mathrm{mL}^{-1}$ 


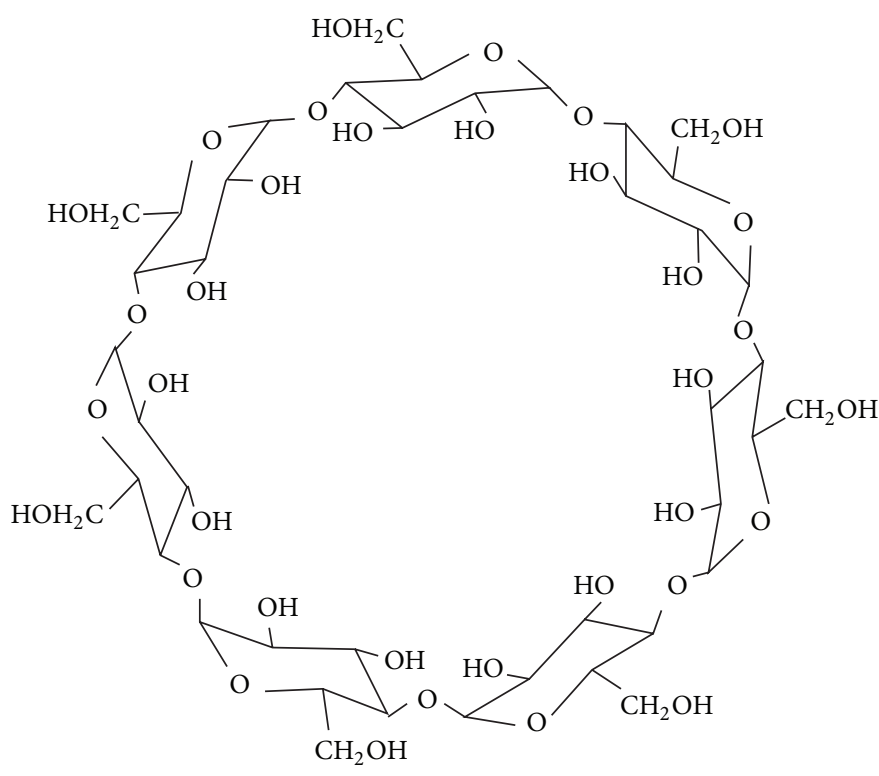

(a)

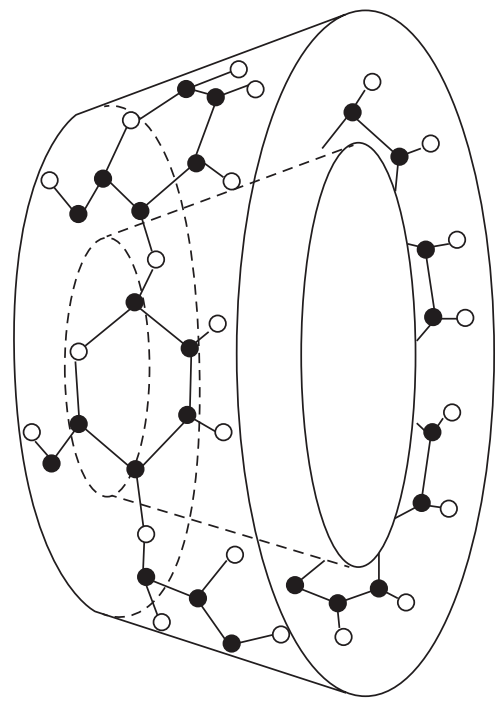

(b)

Figure 2: Structure (a) and torus-like shape (b) of $\beta$-CD molecule.

and treated with the ZER-HP $\beta$ CD inclusion complex at $11.43 \mu \mathrm{g} / \mathrm{mL}$ concentration for 24,48 , and $72 \mathrm{~h}$. Morphological appearances of treated cells were compared concurrently with control untreated cells by observing under phase contrast inverted microscopy. Morphological changes that included appearances such as rounding up of cells, plasma membrane blebbing, and cell detachment were observed in treated HepG2 cells.

\subsection{Propidium Iodide (PI) and Acridine Orange (AO) Double} Staining Assay. The AO/PI viability assay is a rapid, highly linear, and functionally correlated assay that has advantages to conventional viability measurement [17]. This analysis examines whether apoptosis may be implicated in mediating cell death in HepG 2 cells treated by the ZER-HP $\beta$ CD inclusion complex. After treatment of HepG2 cells with inclusion complex (at $11.43 \mu \mathrm{g} / \mathrm{mL}$ concentration for 24,48 , and $72 \mathrm{~h}$ ), the cells were harvested and washed with cold PBS twice. The cells were later added with $10 \mu \mathrm{L}$ of fluorescent dyes, (AO/PI) containing acridine orange $(\mathrm{AO}, 10 \mu \mathrm{g} / \mathrm{mL})$, and propidium iodide (PI, $10 \mu \mathrm{g} / \mathrm{mL}$ ) at equal volumes of each. Freshly stained cell were observed under confocal microscope (LSM 5 Pascal Zeiss, Germany) within 30 minutes before the fluorescence colour starts to fade.

2.6. Assessing Apoptosis Using Annexin V-FITC Assay. Annexin V-FITC Assay was done using the AbD Serotec Annexin V-FITC assay kit (ANNEX100F, USA) in which staining of Annexin V-FITC and propidium iodide was done towards the cells specifically. Fluorochrome FITC-labelled Annexin $\mathrm{V}$ is a sensitive protein probe which possesses high affinity towards phosphatidylserine (PS). Briefly, the assay was done according to the manufacturer's instruction. The binding buffer was diluted in $1: 4$ ratios $(50 \mathrm{~mL}$ binding buffer $+150 \mathrm{~mL}$ distilled water). HepG2 cells, at concentration of $2 \times 10^{5}$ cells $\mathrm{mL}^{-1}$, were seeded into $25 \mathrm{~mL}$ culture flask and treated with the ZER-HP $\beta$ CD inclusion complex at $11.43 \mu \mathrm{g} / \mathrm{mL}$ concentration. After 6,12 , and $24 \mathrm{~h}$ of incubation, the cells were harvested and washed with cold PBS twice. Cells were resuspended in prediluted binding buffer and $5 \mu \mathrm{L}$ Annexin V-FITC was added to $195 \mu \mathrm{L}$ of the cell suspension, mixed well, and incubated for 10 minutes in the dark at room temperature. The cells were then washed with $190 \mu \mathrm{L}$ of prediluted binding buffer, followed by the addition of $10 \mu \mathrm{L}$ of the PI solution, and analysed immediately with flowcytometer (BD FACS Canto II, USA).

2.7. Cell Cycle Arrest Analysis. HepG2 cells at concentration of $2 \times 10^{5}$ cells $\mathrm{mL}^{-1}$ was seeded into $25 \mathrm{~mL}$ culture flask and treated with the ZER-HP $\beta$ CD inclusion complex at $11.43 \mu \mathrm{g} / \mathrm{mL}$ concentration for 24,48 , and $72 \mathrm{~h}$. Untreated cells serve as negative control. The cells were washed with PBS twice to remove any remaining media. To restore cell integrity, fixation of cell population for flowcytometry analysis was performed. Cell pellets were fixed with $90 \%$ cold ethanol by mixing $700 \mu \mathrm{L}$ of $90 \%$ cold ethanol and kept for overnight observation at $-20^{\circ} \mathrm{C}$. The cells were washed using $2 \mathrm{~mL}$ PBS twice. Cell pellet was resuspended with $600 \mu \mathrm{L}$ of PBS $+10 \mathrm{mg} / \mathrm{mL}$ RNase $+1 \mathrm{mg} / \mathrm{mL}$ propidium iodide (PI). PI has the ability to bind to RNA, and hence, RNAse enzyme was added in order to allow PI to bind directly to DNA. The cells were then incubated between $30 \mathrm{~min}$ to $1 \mathrm{~h}$ at $37^{\circ} \mathrm{C}$. Finally, 
the cell cycle kinetics was examined using flowcytometer (BD FACS Canto II, USA). The fluorescence intensity of sub- $\mathrm{G}_{1}$ cell fraction represents apoptotic cell population.

2.8. High Content Screening Assay. This study was conducted using Cellomics Multiparameter Cytotoxicity 3 Kit as described previously [18-20]. Briefly, cells were treated with ZER-HP $\beta C D$ inclusion complex at $11.43 \mu \mathrm{g} \mathrm{mL}^{-1}$ concentration. Untreated cells serve as negative control, whilst paclitaxel $(3.68 \mu \mathrm{g} / \mathrm{mL})$ was used as the positive control. The 96-well microplate was then incubated for 24,48 , and $72 \mathrm{~h}$. In this assay, four important parameters related to apoptosis characteristics were observed simultaneously, which included nuclear morphology changes; changes in cell permeability, mitochondrial membrane potential changes, and cytochrome c release. Plates were analyzed using the ArrayScan HCS system (Cellomics, USA).

2.9. Human Apoptosis Proteome Profiler Array. Detection of the relative levels of apoptosis-related markers was done using Human Apoptosis Antibody Array Kit (RayBio, USA), according to the manufacturer's instruction. Briefly, cells were treated with ZER-HP $\beta$ CD inclusion complex at $11.43 \mu \mathrm{g} / \mathrm{mL}$ concentration. Untreated cells serve as negative control. The human apoptosis array was incubated overnight with $300 \mu \mathrm{g}$ proteins from each sample. Quantification of the apoptosis array was done using the BiOspectrum AC ChemiHR40 (UVP, Upland, CA, USA) via scanning the membrane, and analysis was done using image analysis software according to the manufacturer's instruction.

2.10. Caspase Bioluminescent Assay. Caspase 3/7, caspase 8, and caspase 9 activities were measured in HepG2 cells using a Caspase-Glo assay kit (Promega, USA). HepG2 cells were plated at concentration of $2 \times 10^{5}$ cells $\mathrm{mL}^{-1}$ in a white walled 96-well plate and treated with ZER-HP $\beta C D$ inclusion complex at $11.43 \mu \mathrm{g} / \mathrm{mL}$ concentration for 24,48 , and $72 \mathrm{~h}$. Untreated cells serve as negative control. The Caspase-Glo Reagent was mixed well and allowed to equilibrate to room temperature before starting the assay. The 96-well plate containing cells was removed from the incubator and allowed to equilibrate to room temperature as well. Then, $100 \mu \mathrm{L}$ of Caspase-Glo Reagent was added to each well of the 96well plate containing $100 \mu \mathrm{L}$ of blank (vehicle only), negative control cells, or treated cells in culture medium. The contents of wells were gently mixed by using a plate shaker at 300$500 \mathrm{rpm}$ for 30 seconds and incubated at room temperature between $30 \mathrm{~min}$ to $3 \mathrm{~h}$. The luminescence of each sample was measured in a luminescence microplate reader (Infinite M200 PRO Tecan, Austria). Concisely, the proluminescent substrate containing the DEVD, LETD, and LEHD (sequence is in a single-letter amino acid code) is cleaved by caspase $3 / 7$, caspase 8 , and caspase 9 , respectively. After the caspase cleavage, a substrate for luciferase (aminoluciferin) is released which eventually results in the luciferase reaction and the production of luminescent signal analysed in the luminescence microplate reader.
2.11. Western Blot Analysis. HepG2 cells were treated with ZER-HP $\beta C D$ inclusion complex for 3, 6, 12, and $24 \mathrm{~h}$. Untreated cells serve as negative control. The total proteins of cells were extracted using cell lysis buffer (50 mM Tris-HCL $\mathrm{pH}$ 8.0, $120 \mathrm{mM} \mathrm{NaCl}, 0.5 \%$ NP-40, $1 \mathrm{mM}$ PMSF), and $40 \mu \mathrm{g}$ of the protein extract was separated by $10 \%$ SDS PAGE then transferred into a polyvinylidenedifluoride (PVDF) membrane (Bio-Rad, USA) using semidry transfer unit (Hoefer TE 70X, USA) blocked with 5\% nonfat milk in TBS-Tween buffer (0.12 M tris-base, $1.5 \mathrm{M} \mathrm{NaCl}, 0.1 \%$ Tween20) for 1 hour at room temperature. PVDF membrane was then incubated with the appropriate primary antibody overnight at $4^{\circ} \mathrm{C}$, then it was incubated with horseradish peroxidase conjugated secondary antibody for 30 minutes at room temperature. The bound secondary antibody was detected with peroxidaseconjugated anti-rabbit antibody $(1: 10000)$ or anti-mouse antibody $(1: 10000)$ followed by detection using colorimetric method. The following primary antibodies $\beta$-actin $(1: 10000)$, Bcl-2 (1:1000), Bax (1:1000), and Hsp-70 (1:1000) used in this study were purchased from Santa Cruz Biotechnology, Inc., California, USA.

2.12. Statistical Analysis. Statistical analysis of all experimental data was performed using Student's $t$-test where $P<0.05$ was considered statistically significant where results were presented as mean \pm SD for at least three analyses for each sample.

\section{Results}

3.1. Antiproliferative Activity. A few types of cell viability were determined by conducting the MTT assay. The $\mathrm{IC}_{50}$ values of the ZER-HP $\beta C D$ inclusion complex against five tested cancer cell lines (HepG2, MCF-7, MDA-MB-231, CEMss, and $\mathrm{HeLa}$ ) including one normal hepatic cell line (WRL68) are shown in Table 1 . The treated HepG2 cells showed a decrement of metabolic activity with an $\mathrm{IC}_{50}$ value of $11.43 \pm$ $0.31 \mu \mathrm{g} \mathrm{mL}^{-1}$. The $\mathrm{IC}_{50}$ value obtained for pure ZER alone against HepG2 cells was $15.54 \pm 0.15 \mu \mathrm{g} \mathrm{mL}^{-1}$, and it shows a similar cytotoxicity effect as exhibited by the ZER-HP $\beta C D$ inclusion complex. Paclitaxel, a commercial anticancer drug, was evaluated as positive control to demonstrate concurrent cytotoxicity with an $\mathrm{IC}_{50}$ of $3.68 \pm 0.22 \mu \mathrm{g} \mathrm{mL}^{-1}$. According to the American National Cancer Institute, a bioactive compound with an $\mathrm{IC}_{50}$ value of $\leq 30 \mu \mathrm{g} / \mathrm{mL}$ has the potential to be an anticancer agent.

3.2. ZER-HPßCD Inclusion Complex Showing Morphological Changes on HepG2 Cells That Associate with Apoptosis. Treatment of ZER-HP $\beta C D$ inclusion complex $(11.43 \mu \mathrm{g} / \mathrm{mL})$ on HepG2 cells showed a cell degenerative in a time-dependent manner while untreated HepG2 control cells were viable and showed normal morphology under normal inverted microscopy (Figure 3). To confirm the apoptosis mechanism of cell death, we examined the nuclear morphological changes using AO/PI double staining. HepG2 cells treated with ZER$\mathrm{HP} \beta \mathrm{CD}$ inclusion complex showed cell blebbing and nuclear 


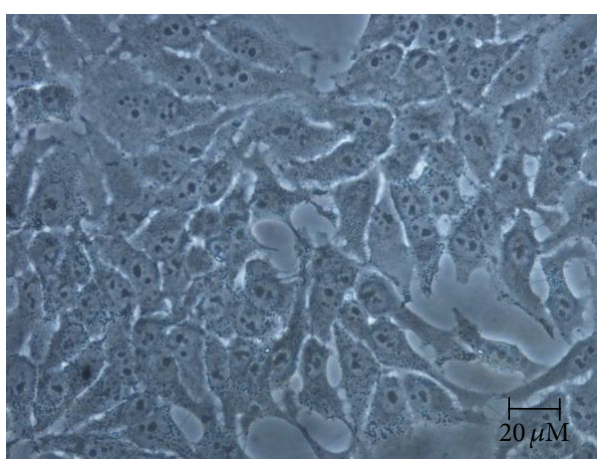

(a)

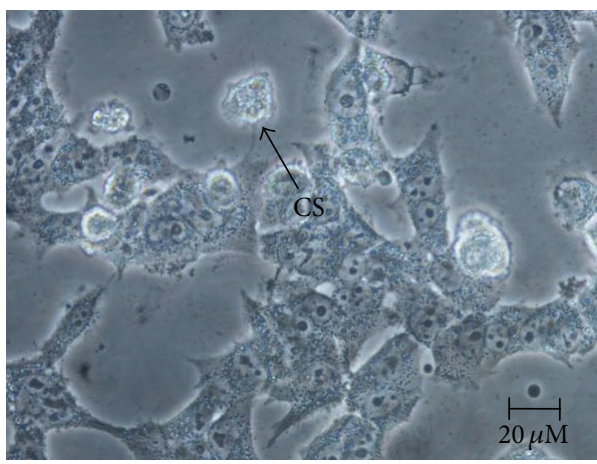

(c)

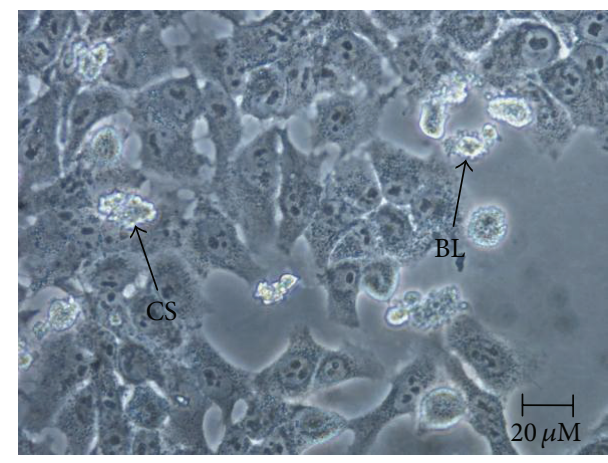

(b)

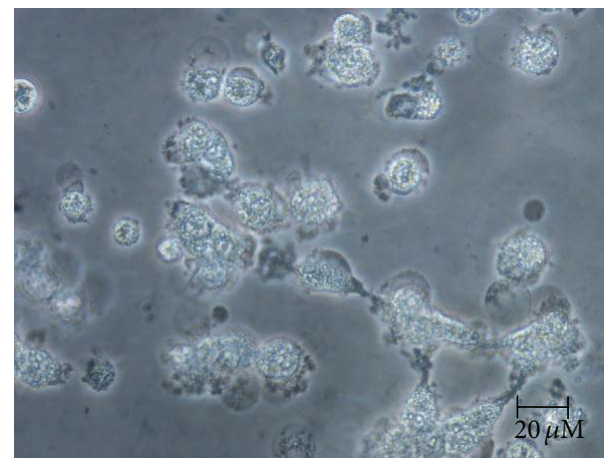

(d)

FIGURE 3: Normal phase contrast inverted micrographs of HepG2 cells treated with $11.43 \mu \mathrm{g} / \mathrm{mL}$ ZER-HP $\beta$ CD inclusion complex. (400x magnification) (a) Control untreated cells; (b) $24 \mathrm{~h}$ treatment (most of the cells having normal morphology with few cells showing membrane blebbing); (c) $48 \mathrm{~h}$ treatment (detachment of cells, prominent growth inhibition and membrane blebbing showing apoptogenic morphology); (d) $72 \mathrm{~h}$ treatment (most of the cells were detached with obvious cell shrinkage). CS: cell shrinkage; BL: cell membrane blebbing.

chromatin condensation of moderate apoptosis after a 24 hour treatment, with subsequent increase at $48 \mathrm{~h}$ of treatment followed by the presence of reddish-orange colour after $72 \mathrm{~h}$ of treatment due to AO binding towards denatured DNA, thus confirming late stage apoptosis (Figure 4).

3.3. ZER-HP $\beta C D$ Inclusion Complex Triggers Early Apoptosis Cell Death in HepG2 Cell Line. Early apoptotic population is indicated by positive Annexin V and negative PI whilst late apoptotic population is indicated by both positive Annexin $\mathrm{V}$ and PI. The result obtained is summarized in Table 2. After $6 \mathrm{~h}$ of HepG2 cells treatment with ZER-HP $\beta$ CD inclusion complex $\left(11.43 \mu \mathrm{gmL}^{-1}\right)$, early apoptotic population significantly increased to $9.0 \%$. After $12 \mathrm{~h}$ of treatment, early apoptotic population was significantly higher than untreated HepG2 control cells at $8.80 \%$ with a decrement of viable cells at $88.80 \%$. After $24 \mathrm{~h}$ of treatment, decrement of viable cells continued with $79.30 \%$, and both early and late apoptotic cell populations rose significantly at $15.20 \%$ and $5.50 \%$, respectively $(P<0.05)$. These results prove that the treatment of ZER-HP $\beta C D$ inclusion complex on HepG2 cells induced apoptosis, with possible translocation of phosphatidylserine from cytoplasm to the transmembrane of the HepG2 cells.
TABLE 1: Cytotoxicity of ZER-HP $\beta$ CD inclusion complex on different cancer and normal cells in vitro.

\begin{tabular}{llc}
\hline Cell line & Origin of cells & $\mathrm{IC}_{50}(\mu \mathrm{g} / \mathrm{mL})$ \\
\hline HepG2 & $\begin{array}{l}\text { Liver hepatocellular cells } \\
\text { MCF-7 }\end{array}$ & $\begin{array}{l}\text { Oestrogen receptor-positive } \\
\text { breast adenocarcinoma cells }\end{array}$ \\
MDA-MB-231 & $\begin{array}{l}\text { Oestrogen receptor-negative } \\
\text { breast adenocarcinoma cells }\end{array}$ & $15.32 \pm 0.61$ \\
CEMss & T-acute lymphoblastic leukemia & $9.13 \pm 0.38$ \\
HeLa & Cervical cancer cells & $14.47 \pm 0.26$ \\
WRL-68 & Normal hepatic cell line & $>30$ \\
\hline
\end{tabular}

$\mathrm{IC}_{50}$ values were obtained from MTT assay. Data are reported as means $\pm \mathrm{SD}$ for measurements in triplicate.

3.4. ZER-HPßCD Inclusion Complex Induces Apoptosis with G2/M Phase Cell Cycle Arrest. HepG2 cells treated with ZER$\mathrm{HP} \beta \mathrm{CD}$ inclusion complex $(11.43 \mu \mathrm{g} / \mathrm{mL})$ revealed a significant time-dependent increase $(P<0.05)$ in hypodiploid subG0/G1 DNA fraction, which corresponds to the presence of apoptotic cells (Figure 6). Sub-G0/G1 fraction in untreated control cells was $0.20 \%$, and this value subsequently increased to $24.20 \%$ after $72 \mathrm{~h}$ of treatment with ZER-HP $\beta$ CD inclusion 


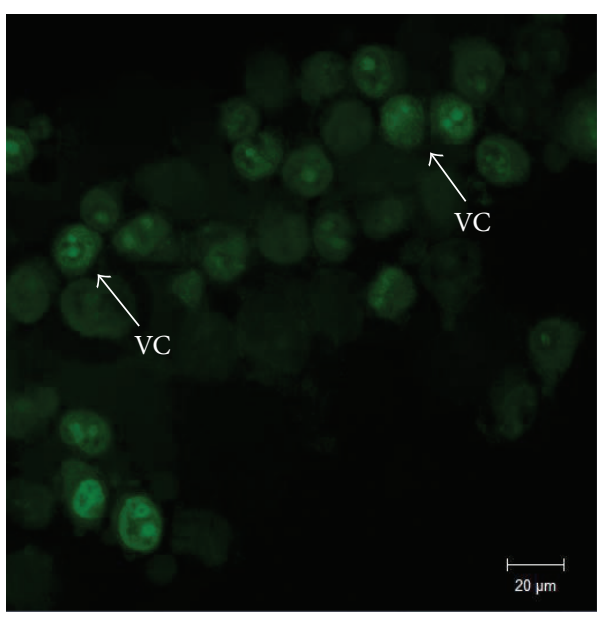

(a)

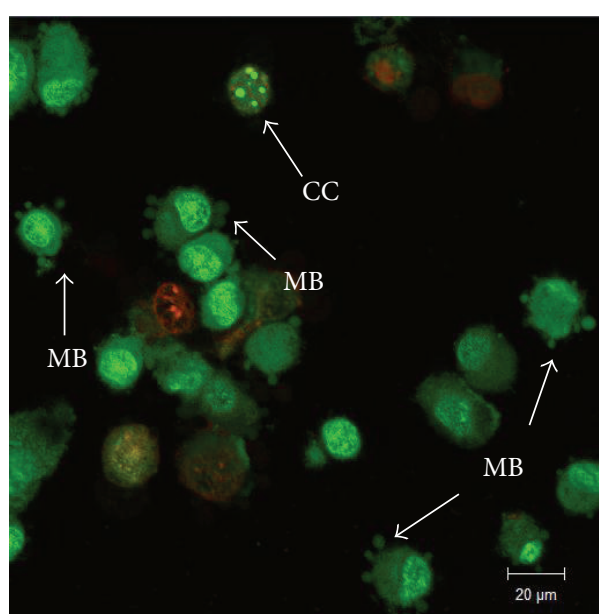

(c)

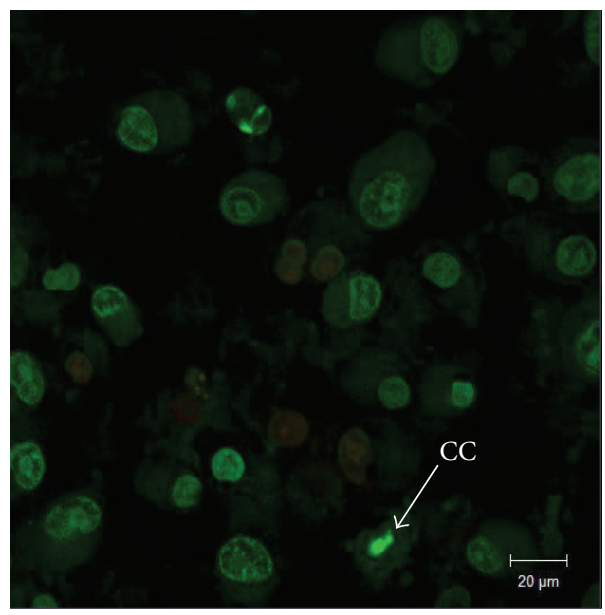

(b)

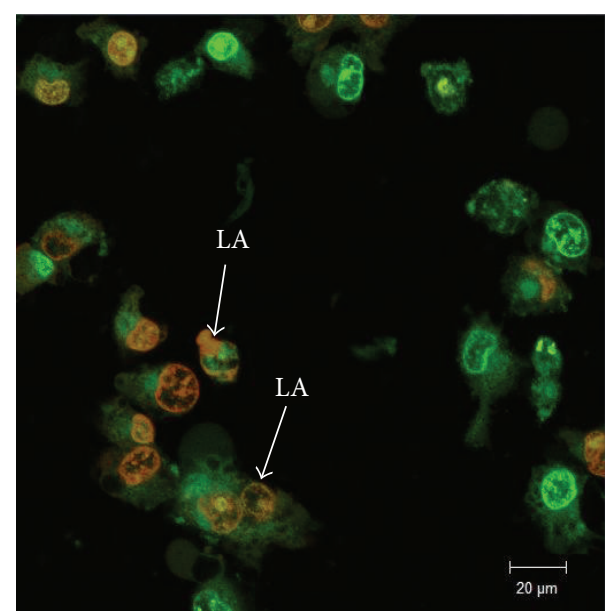

(d)

FIGURE 4: Confocal micrographs of acridine orange and propidium iodide double-stained HepG2 cells treated with 11.43 $\mu \mathrm{g} / \mathrm{mL}$ ZER-HP $\beta$ CD inclusion complex. (400x magnification) (a) Untreated cells showed normal structure without prominent apoptosis; (b) early apoptosis features were seen after $24 \mathrm{~h}$ representing intercalated acridine orange (bright green) amongst the fragmented DNA; (c) more cells showing membrane blebbing after $48 \mathrm{~h}$; (d) presence of reddish-orange colour at $72 \mathrm{~h}$. VC: viable cells; MB: cell membrane blebbing; CC: chromatin condensation; LA: late apoptosis.

TABLE 2: Flow cytometric analysis of Annexin V in HepG2 cells which were treated with $11.43 \mu \mathrm{g} / \mathrm{mL}$ ZER-HP $\beta$ CD inclusion complex for 6, 12 , and 24 hours.

\begin{tabular}{|c|c|c|c|c|}
\hline \multirow{2}{*}{ Cell condition } & \multicolumn{4}{|c|}{ Percentage of cells (\%) } \\
\hline & Control & $6 \mathrm{~h}$ & $12 \mathrm{~h}$ & $24 \mathrm{~h}$ \\
\hline Viable & $93.90 \pm 1.20$ & $89.70 \pm 1.50$ & $88.80 \pm 3.20$ & $79.30 \pm 5.80$ \\
\hline Early apoptosis & $4.20 \pm 0.27$ & $9.00 \pm 0.31^{*}$ & $8.80 \pm 0.44^{*}$ & $15.20 \pm 0.40^{*}$ \\
\hline Late apoptosis & $1.90 \pm 0.12$ & $1.30 \pm 0.53$ & $2.30 \pm 0.35$ & $5.50 \pm 0.27^{*}$ \\
\hline
\end{tabular}

Data are shown as mean $\pm \mathrm{SD}(n=3) ;{ }^{*}$ Indicates a significant difference compared with control $(P<0.05)$.

complex. The results further indicated that ZER-HP $\beta C D$ inclusion complex treatment caused mitotic block and cell cycle delay in G2/M phase (Figure 5). The proportion of accumulated cells blocked at G2/M phase significantly $(P<$ 0.05 ) increased to $59.84 \%$ as opposed to $16.44 \%$ for the untreated HepG2 control cells in G2/M phase after a 72-hour treatment (Figure 6).
3.5. ZER-HPßCD Inclusion Complex Reduces Mitochondrial Membrane Potential and Translocates Cytochrome c in HepG2 Cells. The nuclear intensity which corresponds to apoptotic chromatin changes (Figures 7(a) and 8(a)) and cell permeability (Figures 7(a) and 8(a)) were both found to be increased significantly $(P<0.05)$ compared to the untreated control cells. Fluorescence intensity in the membrane potential area 


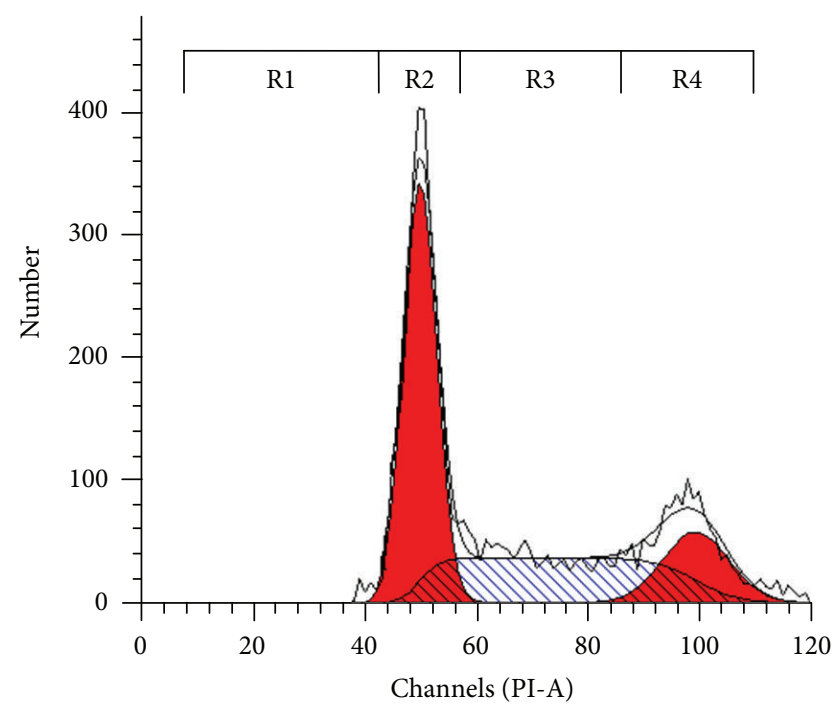

(a)

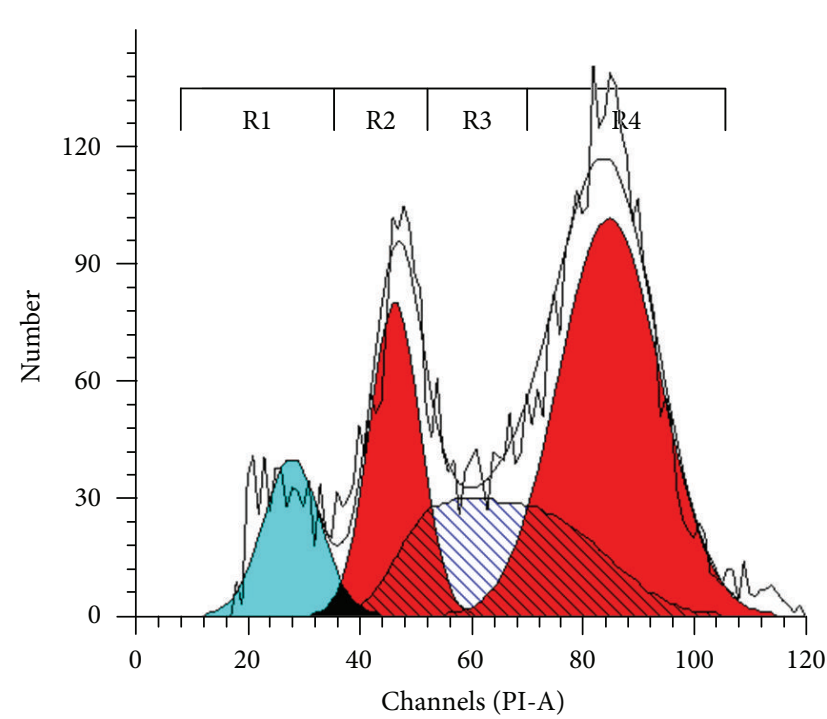

(c)

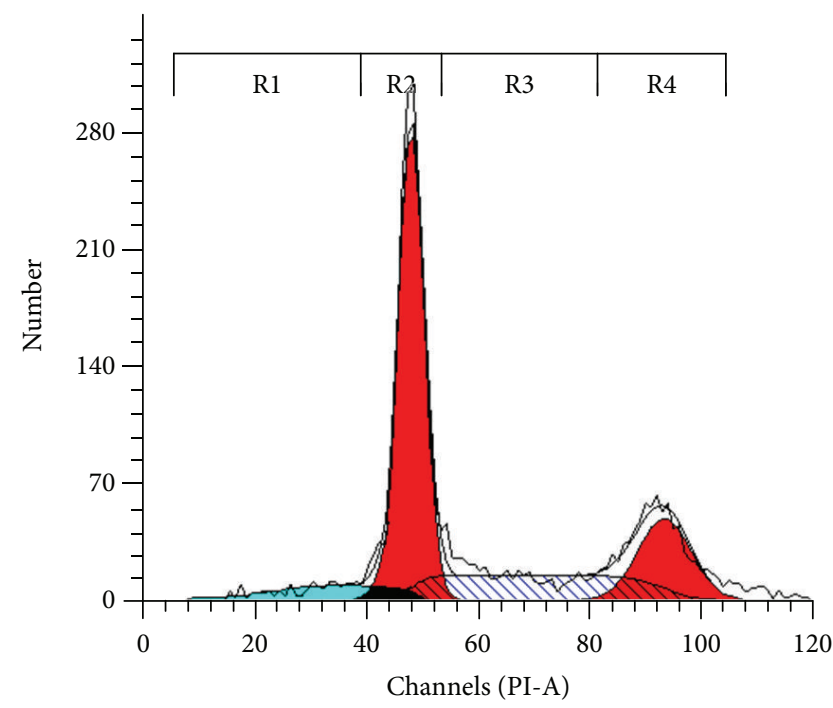

(b)

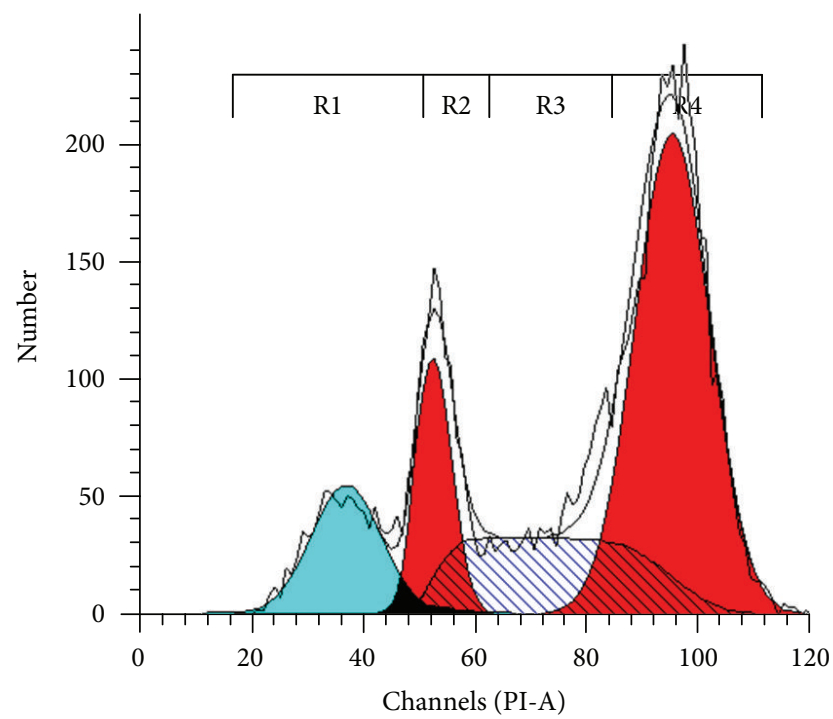

(d)

FIGURE 5: DNA analysis of ZER-HP $\beta$ CD inclusion-complex-treated HepG2. Rapidly proliferating HepG2 cells exposed to $11.43 \mu \mathrm{g} / \mathrm{mL}$ at (b) $24 \mathrm{~h}$, (c) $48 \mathrm{~h}$, (d) $72 \mathrm{~h}$ and (a) control were tested for DNA content. Panels are representative of DNA histograms obtained and subsequently analyzed for DNA content; whereby R1, R2, R3, and R5 indicate sub-G0/G1 (apoptosis cells), G0/G1, S, and G2/M phase, respectively.

of HepG2 cells treated with ZER-HP $\beta$ CD inclusion complex $(11.43 \mu \mathrm{g} / \mathrm{mL})$ was shown to be reduced compared to the untreated control cells (Figure $7(\mathrm{c})$ ), reflecting the collapsing of mitochondrial membrane potential with a significant decrease $(P<0.05)$ and a drastic drop after $72 \mathrm{~h}$ of treatment (Figure $8(\mathrm{c})$ ). Cytochrome $\mathrm{c}$ was released into the cytosol upon treatment, demonstrating possible involvement of the mitochondrial pathway with a significant increase of cytosolic cytochrome $c(P<0.05)$ in a time-independent manner (Figures $7(\mathrm{~d})$ and $8(\mathrm{~d})$ ).

3.6. ZER-HPßCD Inclusion Complex Involves Extrinsic and Intrinsic Apoptosis Pathways. The result obtained from our
Human Apoptosis Antibody Array analysis showed an upregulation of the proapoptotic Bax protein, which correlated to the downregulation of the antiapoptotic $\mathrm{Bcl}-2$ protein (Figure 9). Caspase 8, caspase 3, and cytochrome c showed significant increase while BID was seen to be depleted significantly after the treatment of HepG2 with ZER-HP $\beta C D$ inclusion complex compared to untreated control cells $(P<$ 0.05 ). The upregulation of caspases 8 and 3 supports the possibility that the ZER-HP $\beta C D$ inclusion complex induces cell death in HepG2 cells via apoptosis with the involvement of both intrinsic and extrinsic pathways. In addition, p53 protein showed no significant change, proving that the apoptosis mechanism was p53 independent $(P>0.05)$. Hsp70 , also an antiapoptotic protein, was found to be significantly 


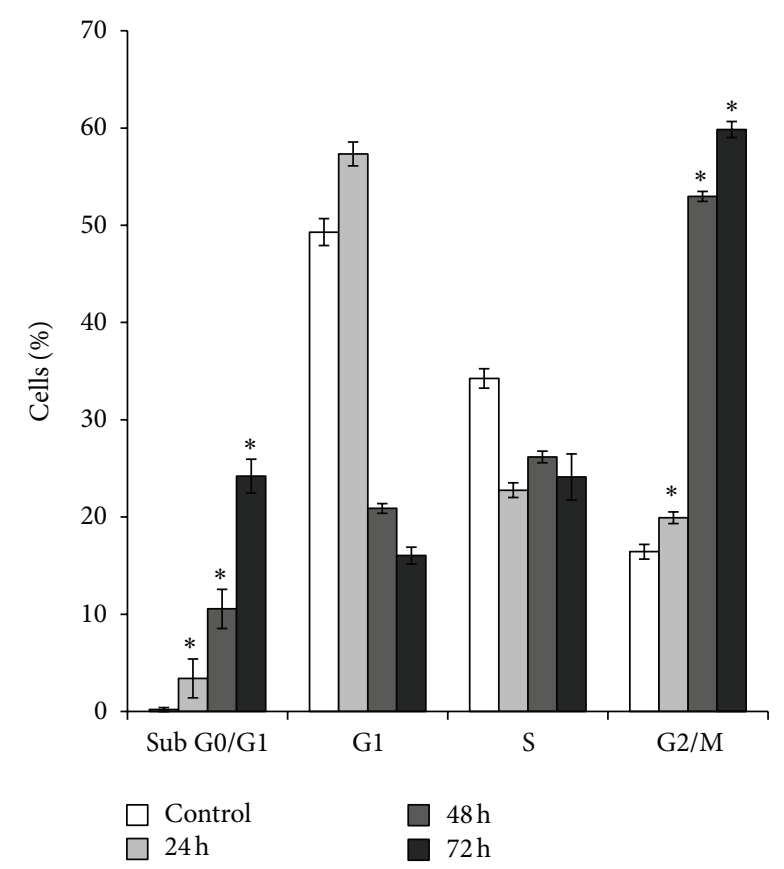

FIgURE 6: Percentages of cell cycle distribution in sub-G0/G1 (apoptosis cells), G0/G1, S, and G2/M phase of HepG2 cells treated with $11.43 \mu \mathrm{g} / \mathrm{mL}$ of ZER-HP $\beta C D$ inclusion complex for 24,48 , and $72 \mathrm{~h}$. Induction of G2/M arrest in cell cycle progression of HepG2 cells by ZER-HP $\beta C D$ inclusion complex. ${ }^{*}$ Indicates a significant difference $(P<0.05)$ compared with control.

decreased $(P<0.05)$. XIAP, an inhibitor of apoptosis protein (IAP) was found to be down-regulated while SMAC that works as the inhibitor to IAP was shown to be up-regulated, providing evidence that both XIAP and SMAC correspond to each other to promote cell death in HepG2 cells.

The luminescence assay was further used to confirm the involvement of caspases proteins in apoptosis induction. The effector caspase, caspase 3/7, was found to be increased as well as the initiator caspases, caspase 9 and caspase 8 (Figures $10(\mathrm{a}), 10(\mathrm{~b})$, and $10(\mathrm{c}))$. As shown in our results, ZER-HP $\beta C D$ inclusion complex significantly stimulated all three caspases $(P<0.05)$ compared to untreated control cells, further suggesting that both intrinsic (mitochondrial pathway) and extrinsic pathways were involved. These results correspond well with our previous results using the Human Apoptosis Antibody Array analysis.

The involvement of $\mathrm{Hsp}-70, \mathrm{Bcl}-2$, and Bax apoptosis proteins was confirmed using Western blot analysis (Figure 11). Protein Hsp-70 could be seen to decrease gradually after $12 \mathrm{~h}$ of treatment without significant changes at $3 \mathrm{~h}$ and $6 \mathrm{~h}$ of treatment with ZER-HP $\beta$ CD inclusion complex. Similar to Hsp-70, Bcl-2 protein exhibited decreased band intensity in a time-dependent manner, showing obvious fading of the colour after $6 \mathrm{~h}$ of HepG2 cells treatment with ZER$\mathrm{HP} \beta \mathrm{CD}$ inclusion complex. On the other hand, Bax that acted as proapoptotic protein increased with the increment of treatment time with the highest band intensity after $24 \mathrm{~h}$, providing evidence that treated HepG2 cells initiated the induction of apoptosis cascade mechanism, which finally resulted in cell death. $\beta$-Actin, used as the loading control, showed equal intensity to all bands, confirming equal protein concentration in all loaded samples.

\section{Discussion}

Due to the growing use of natural-derived substances all around the world, a detailed evaluation of their pharmacological qualities and safety issues is critically needed, since traditional beliefs and remedies cannot stand alone without undergoing detailed scientific studies [21]. Consuming such herbal medicines without proper scientific approval may invite other conflicts which are not favourable to consumers. $Z$. zerumbet is one of the most well-known compounds for its role in traditional medicines as well as in pharmacological activities. ZER is one of the plant bioactive compounds, which can be found mostly in the rhizome of Z. Zerumbet, that was previously reported to produce cytotoxicity through apoptosis induction in various cancers including skin tumor, colon, and lung carcinogenesis, hepatocarcinogenesis, leukemic cancer, and cervical intraepithelial neoplasia [10-14].

Despite the apoptotic effects that ZER demonstrates, ZER was reported to be poorly soluble in water and requires organic solvent to solubilize it. Hence, in our previous research, we prepared an inclusion complex of ZER with $\mathrm{HP} \beta \mathrm{CD}$ and characterized its physicochemical properties. The results provided evidence that ZER fits well inside the nanocavity of HP $\beta C D$. The study further concluded that the complexation of ZER with HP $\beta C D$ leads to crucial modifications pertaining to the physicochemical properties of ZER which includes its solubility, stability, and bioavailability in blood [15]. Thus, taking into consideration the importance of ZER-HP $\beta C D$ new findings as a potential biopharmaceutical drug, the antiproliferative effects of the inclusion complex was investigated to determine its bioactivity in HepG2 cells. This current study is an initiative to investigate the anticancer activity of the inclusion complex that would eventually lead to preclinical studies of ZER-HP $\beta$ CD inclusion complex as a potential anticancer for future treatment of hepatocarcinoma in humans.

The ZER-HP $\beta C D$ inclusion complex was screened against five different human cancer cell lines: HepG2, MCF-7, HeLa, MDA-MB-231, and CEMss. The results obtained showed that ZER-HP $\beta C D$ inclusion complex exhibits cytotoxic activity on all cancer cell lines screened, with $\mathrm{IC}_{50}$ values $<30 \mu \mathrm{g} / \mathrm{mL}$. Pure ZER alone were screened and its activity in HepG2 cells were compared concurrently to that of ZER-HP $\beta C D$ inclusion complex. The determined $\mathrm{IC}_{50}$ values confirmed the previous study of pure ZER alone against cell lines (MCF7, HeLa, MDA-MB-231, and CEMss), where it was found to be nearly similar to the $\mathrm{IC}_{50}$ values obtained for the ZER-HP $\beta$ CD inclusion complex [15]. These results are consistent with our current study, proving that the cytotoxic activities of ZER-HP $\beta$ CD inclusion complex in these cancer cells may possibly resemble that of pure ZER alone. Interestingly, the ZER-HP $\beta C D$ inclusion complex gave an $\mathrm{IC}_{50}$ value of more than $30 \mu \mathrm{g} / \mathrm{mL}$ in the normal hepatic cell line (WRL-68), showing that the cytotoxicity 

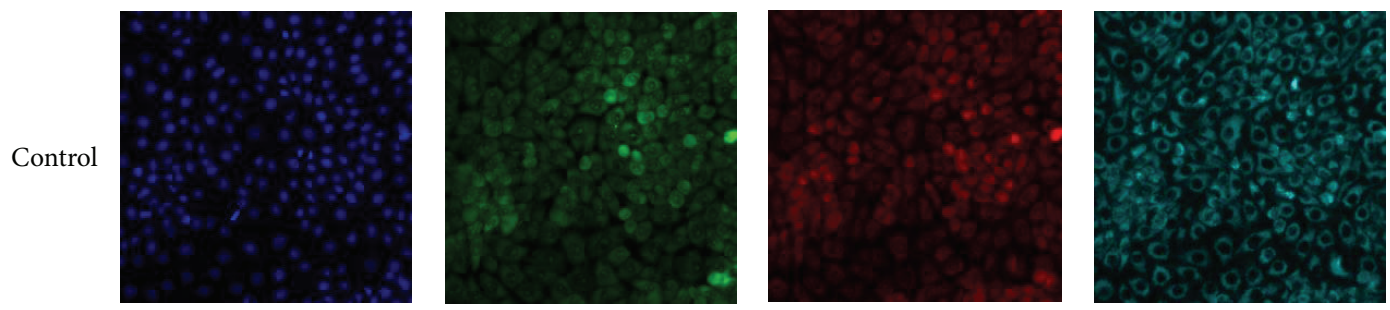

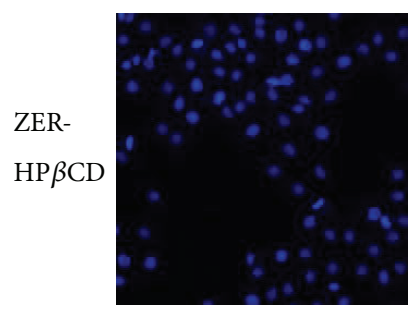

(a) Hoechst 33342

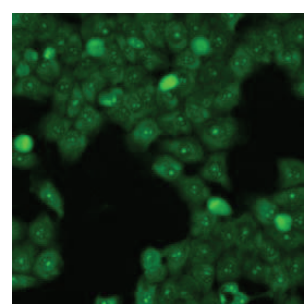

(b) Cell Permeability

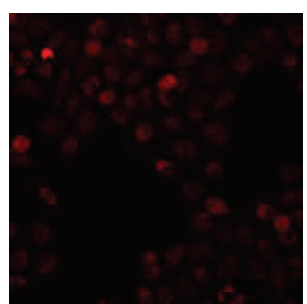

(c) Mitochondrial Membrane Potential

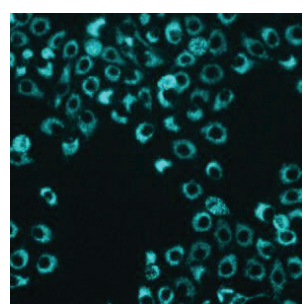

(d) Cytochrome c

FIGURE 7: Fluorescent images of HepG2 cells treated with medium alone and $11.43 \mu \mathrm{g} / \mathrm{mL}$ of ZER-HP $\beta$ CD inclusion complex, stained with (a) Hoechst for nuclear, (b) cell permeability dye, (c) mitochondrial membrane potential dye, and (d) cytochrome c. The images from each row were obtained from the same field of the same treatment sample. ZER-HP $\beta$ CD inclusion complex showed marked increases in permeability dye, marked reduction in mitochondrial membrane potential, and marked increases in cytochrome c.

produced by this inclusion complex is selective in cancer cells only.

The mode of HepG2 cell death was determined based on the characteristics of the cells exerted after treatment. Microscopy analysis has been used as the gold standard for precise detection of cell death, particularly apoptosis, according to the morphological criteria stated by Wyllie et al. (1980) [22] and Yasuhara et al. (2003) [23]. Indications of apoptosis in HepG2 cells treated with ZER-HP $\beta$ CD inclusion complex such as a reduction in the number of cells, detachment of cells, cytoplasmic shrinkage, and membrane blebbing were observed using phase contrast inverted microscopy and confocal microscopy (with AO/PI double staining). The significant increment of apoptotic scores of HepG2 cells treated with ZER-HP $\beta$ CD inclusion complex correlates with a previous study, which reported that HepG2 cells treated with pure ZER lead to a large increase of apoptotic scores at approximately $80 \%$ by $48 \mathrm{~h}$ and $90 \%$ after $72 \mathrm{~h}$ [24].

However, morphological studies alone is not sufficient to validate the early and late apoptosis; thus, the finding was further evaluated using the Annexin V assay, which demonstrated that early apoptosis in HepG2 cells was significantly increased in a time-dependent manner after treatment with ZER-HP $\beta C D$ inclusion complex. The critical event during apoptosis is when the changing plasma membrane signals phagocytes to allow them to engulf cells undergoing apoptosis before rupturing [25]. Modification of the apoptotic cell surface included the exposure of phosphatidylserine (PS), which normally dominates surface membrane facing the cytosol [26]. PS externalization occurs in early apoptosis event before the cell undergoes nuclear changes, regardless of the initiator apoptosis catalyst [27]. Hence, early phases of apoptosis (prior to the loss of cell membrane integrity) were detected using the fluorescein isothiocyanate (FITC) conjugated Annexin V (protein with high affinity for PS) binding assay of PS, allowing measurement and therefore scoring of individual apoptotic cells [25]. Our results in this current study are parallel with the significant increase of apoptosis in HepG2 cells at 6,12 , and 24 h treatments, which proved that the ZER-HP $\beta C D$ inclusion complex is able to trigger early apoptosis with the exposure of PS at the external surface of treated HepG2 cells.

To further elucidate the probable mechanisms of apoptosis induced by ZER-HP $\beta$ CD inclusion complex in HepG2 cells, cell cycle analysis was performed and evaluated. The observed results showed a hypodiploid sub-G0/G1 DNA accumulation, which concluded that the ZER-HP $\beta C D$ inclusion complex is able to induce apoptosis in HepG2 cells in a time-dependent manner and simultaneously induce cell cycle arrest at G2/M. This mitotic blockage has been observed as a result of treating HepG2 cells with the accumulation of ZER$\mathrm{HP} \beta \mathrm{CD}$ inclusion complex at G2/M. It has been reported that the $\mathrm{G} 2 / \mathrm{M}$ arrest triggers possible phosphorylation of apoptosis-associated proteins in the mitotic phase of cell cycle, which further explains the involvement of G2/M arrest to be associated with apoptosis [28]. This result was confirmed by previous studies done on pure ZER alone, which was found to inhibit interleukin- 6 and induces apoptosis and cell cycle arrest at G2/M phase in ovarian (Caov-3) and cervical (HeLa) cancer cells [29]. It was also previously reported elsewhere that ZER concurrently showed apoptogenic effects to induce G2/M cell cycle arrest in promyelocytic leukemia NB4 cells and colon adenocarcinoma HT-29 cell line [30, 31].

A molecular study was conducted to clarify probable mechanisms of apoptosis induced by ZER-HP $\beta C D$ inclusion complex using high-content screening assay, proteome profiler array, caspase luminescence assay, and Western blot analysis. The study confirmed that ZER-HP $\beta$ CD inclusion 


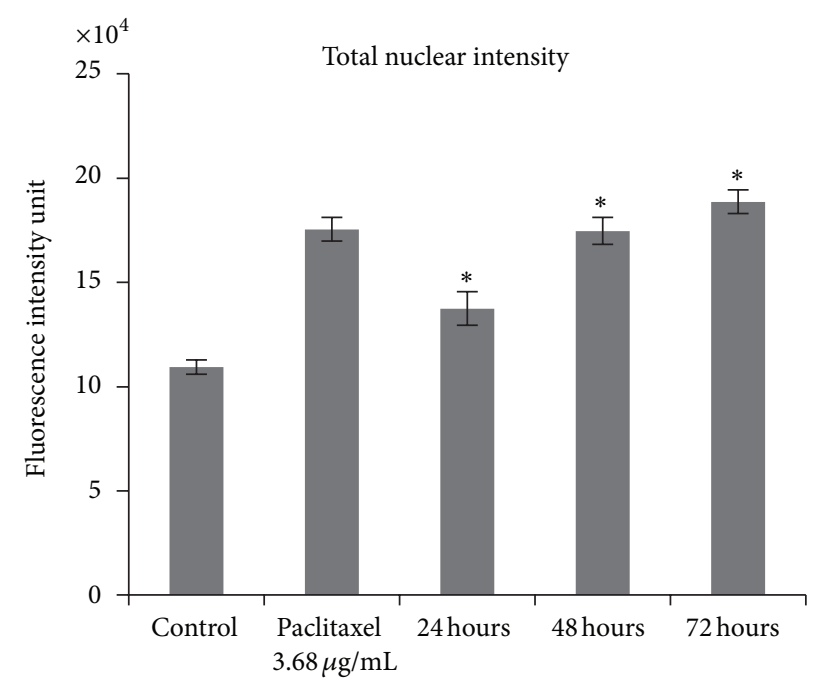

(a)

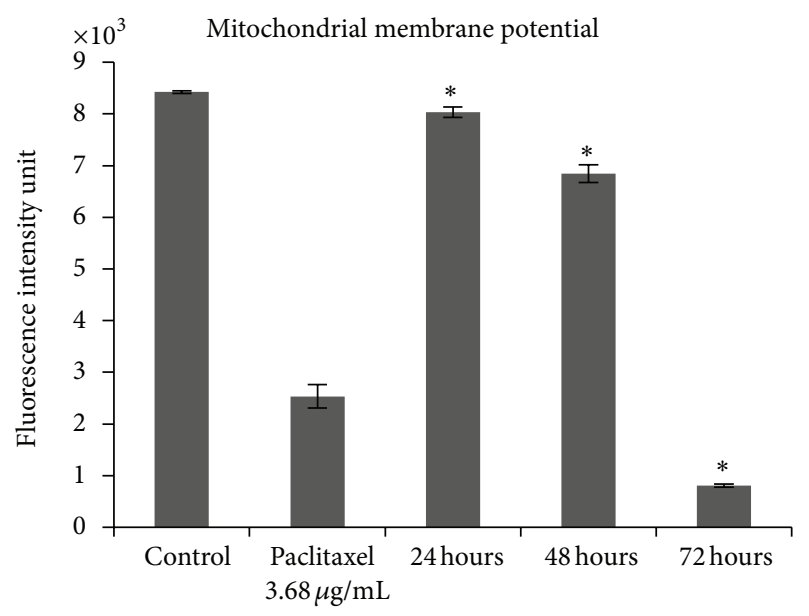

(c)

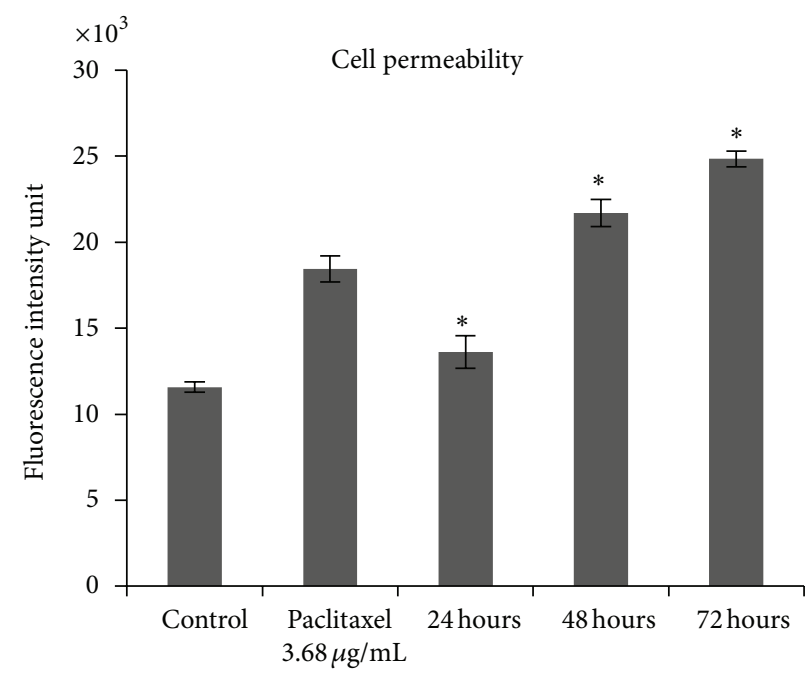

(b)

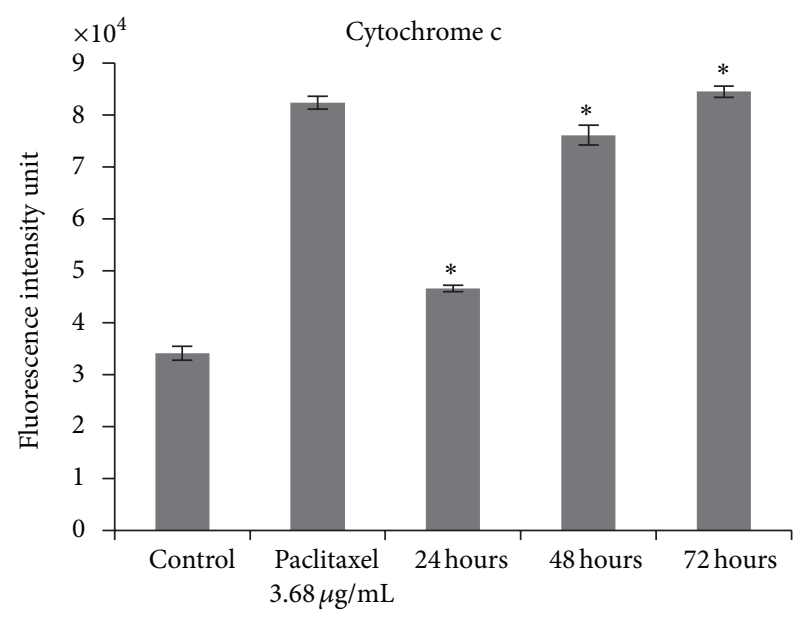

(d)

FIGURE 8: Quantitative analysis of ZER-HP $\beta$ CD inclusion complex mediated apoptosis parameter. Changes in (a) total nuclear intensity, (b) cell permeability, (c) mitochondrial membrane potential, and (d) cytochrome c localization were all measured simultaneously in HepG2 treated cells. Treatment with ZER-HP $\beta$ CD inclusion complex showing statistically significant cell loss (data not shown), increased total nuclear intensity, increased cell permeability, loss of mitochondrial membrane potential, and cytochrome $\mathrm{c}$ release from the mitochondria with good $P$ values. Each experiment was performed at least two times. ${ }^{*}$ Indicates a significant difference $(P<0.05)$ compared with control.

complex stimulates apoptosis signal, causing a decrement of membrane permeability in HepG2 cells followed by mitochondrial transmembrane potential $(\Delta \Psi \mathrm{m})$ changes. The structure and dynamics of the altered cell membrane in HepG2 cells are due to this increment of susceptibility to hydrolysis; thus, increasing cell permeability and finally events leading to apoptosis [32]. Any stimulus causing apoptosis affects HepG2 cells in such a way that will cause permeability transition pores to open to the inner mitochondrial membrane, subsequently causing increased permeability of the inner mitochondrial membrane capable of soluting molecular mass of less than about $1500 \mathrm{Da}$, thus resulting in the depletion of $\Delta \Psi \mathrm{m}$, and in turn, the release of proapoptotic proteins and the arrest of the bioenergetic function of the organelle [33-35].
The present study further demonstrated that the exposure of HepG2 cells to ZER-HP $\beta$ CD inclusion complex showed an upregulation of proapoptotic protein, Bax, and a downregulation of antiapoptotic, $\mathrm{Bcl}-2$ protein. Bax and other related proapoptotic proteins activities were affected by the formation of $\mathrm{Bcl}-2$ antiapoptotic protein. Bax will be translocated to the mitochondria and other membrane sites, which activates the transformation of mitochondrial function. This mitochondrial transformation will cause loss of transmembrane potential and release of cytochrome c to the cytosol, resulting in apoptotic cell death [36]. Overexpression of Bcl2 will prevent the release of cytochrome c, causing HepG2 cells to be resistant to apoptotic induction [37]. Contrary to this, ZER-HP $\beta C D$ inclusion complex was able to suppress Bcl-2 expression, thus allowing Bax to form a homodimer 


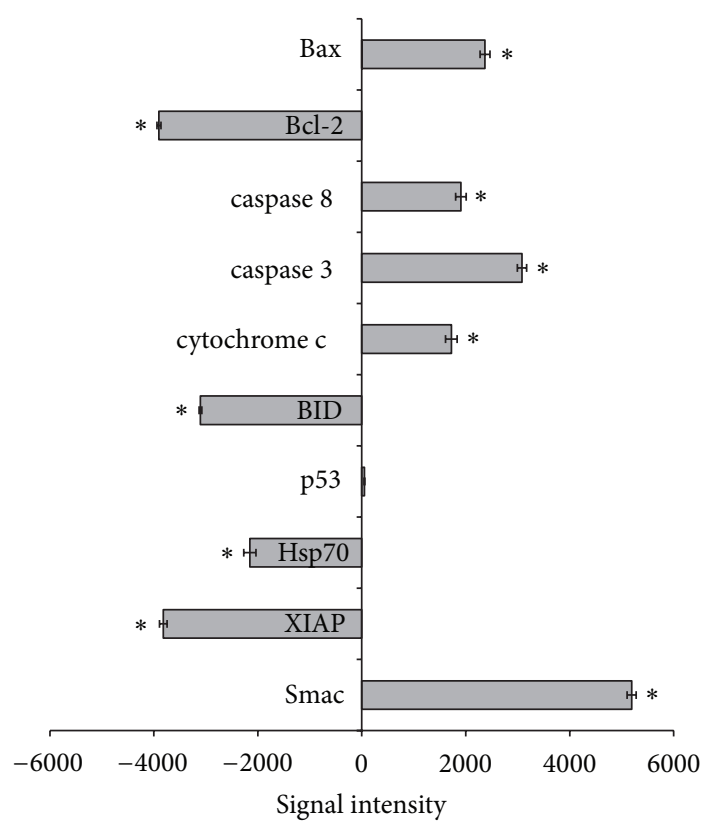

FIGURE 9: Human apoptosis proteome profiler array analysis in HepG2 cells treated with $11.43 \mu \mathrm{g} / \mathrm{mL}$ of ZER-HP $\beta$ CD inclusion complex for $48 \mathrm{~h}$. Graph shows the difference between treated and control untreated cells. ${ }^{*}$ Indicates a significant difference $(P<0.05)$ compared with control.

with another Bax instead of forming a heterodimer with Bcl2. These upregulation and downregulation of Bax and Bcl-2 ratio reaffirm a previous study which reported that pure ZER alone induced apoptosis in HepG2 cells via modulation of $\mathrm{Bax} / \mathrm{Bcl}-2$ ratio [36].

Results of the caspase luminescence assay and apoptosis proteome profiler array further demonstrated that ZER$\mathrm{HP} \beta \mathrm{CD}$ inclusion complex treatment induces the upregulation of caspase 8 , caspase 9, caspase 3, and cytochrome c, and degradation of BID in treated HepG2 cells. The upregulation of caspase 8 was due to the proteolysis of procaspase 8 , forming activated caspase 8 and therefore allowing the amplification of caspase signal for apoptosis [38]. In a previous study elsewhere, commercial drugs such as daunorubicin, doxorubicin, etoposide, and mitomycin $\mathrm{C}$ induced apoptosis in Jurkat leukemic T cells involving the activation of caspase 8 [39]. Paclitaxel was also reported to induce apoptosis involving caspase 8 activation in colon cancer cell (HT-29-D4) [40]. Activated caspase 8 will cleave BID into a proapoptotic fragment called truncated BID (tBID), which will later translocate to the mitochondrial membrane with a subsequent release of cytochrome $c$ into the cytosol with the help of Bax [41]. Cleavage of BID is mediated by caspase 8 , which is known to connect the extrinsic and mitochondrial pathways in apoptosis cell death [42]. Cytochrome $\mathrm{c}$ release will induce the oligomerization of cytochrome c/Apaf-1/caspase 9 complex that activates caspase 9 and finally leads to the cleavage of downstream effector caspase 3 and 7 [43].

The protein expression of p53 did not exhibit any significant changes in HepG2 cells treated with ZER-HP $\beta C D$ inclusion complex, providing evidence for the first time that induced apoptosis upon treatment of HepG2 cells with ZER$\mathrm{HP} \beta \mathrm{CD}$ inclusion complex is p53 independent. Although p53 is known as the "guardian of the genome" since it prevents proliferation of damage cells, several chemotherapy drugs such as paclitaxel, tamoxifen, and vinkristin were identified as able to induce apoptosis without the involvement of p53 [44-46]. This is probably due to the expression of Bax protein, which after achieving certain level is able to induce apoptosis without the presence of p53 [44]. Our current finding is crucial as most cancer tumours including those of the breasts, lung, colon, bladder, brain, bone, hematopoietic, and muscle tissues are initiated due to the abnormalities of or mutated p53 gene [47]. This would allow the ZER-HP $\beta C D$, a significant anticancer, complex to be able to trigger the induction of apoptosis in most human cancers that are p53 dependent.

Heat shock protein (Hsp) 70 will interfere with the apoptotic process of cell death as its role is to mediate cellular protection by preventing cytochrome c/dATP-mediated caspase activation but allowing the formation of Apaf-1 oligomers to be accessible. Hsp-70 binds to Apaf-1 but not to procaspase 9, therefore preventing the recruitment of caspases to the apoptosome complex. This directly blocks the assembly of functional apoptosome and prevents the cell from undergoing apoptosis [48]. In this current study, Hsp70 was found to be suppressed in HepG2 treated with ZER$\mathrm{HP} \beta \mathrm{CD}$ inclusion complex, resulting in the Apaf- 1 functional assembly blockage to be prevented. Protein Hsp-70 was also found to be decreased gradually only after $12 \mathrm{~h}$ of treatment without any significant changes at $3 \mathrm{~h}$ and $6 \mathrm{~h}$ of treatment. In accordance with this, it may be suggested that the host stress response of HepG2 cells may be activated at 3 and $6 \mathrm{~h}$ of treatment but with Hsp-70 exhibiting no significant 


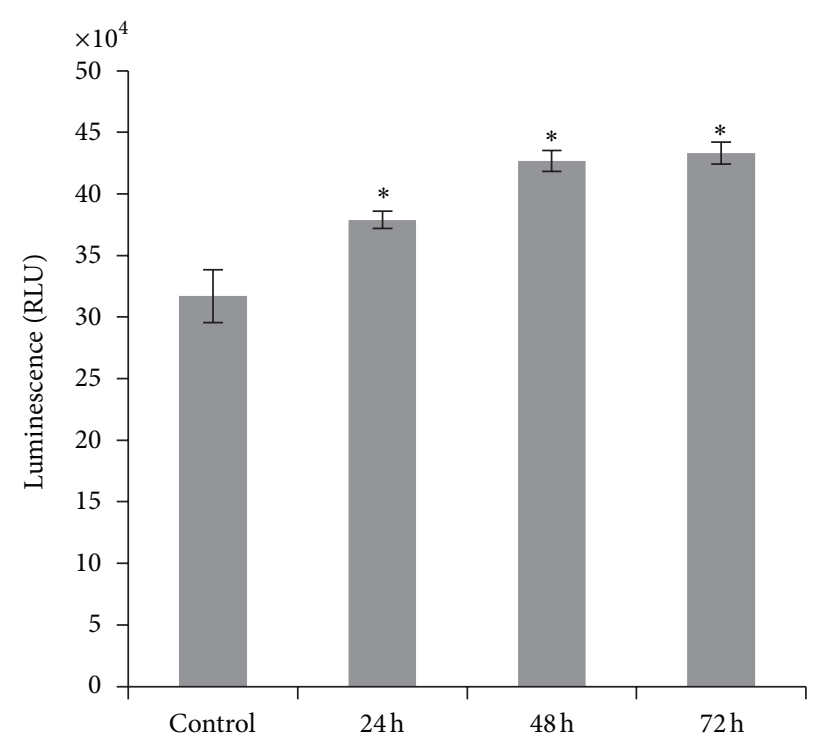

(a)

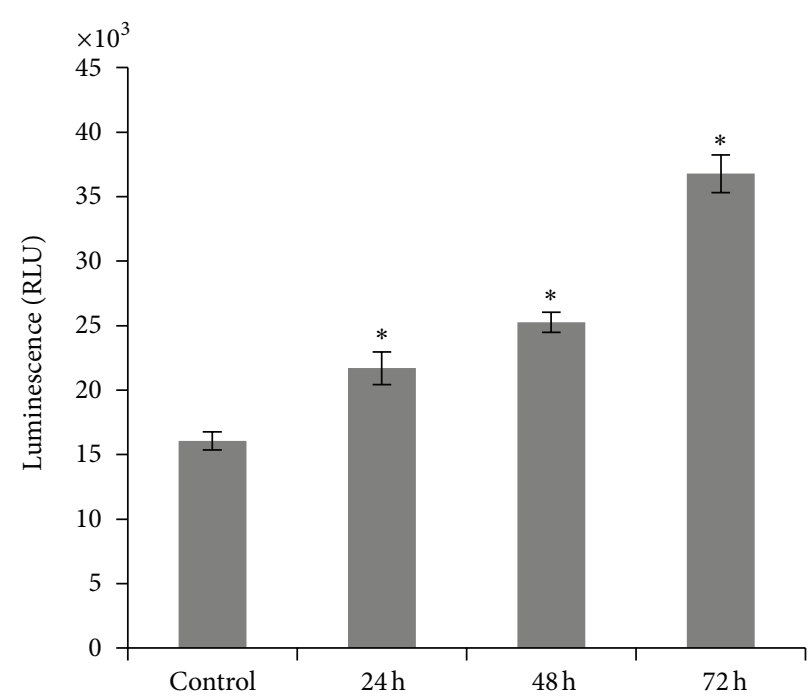

(b)

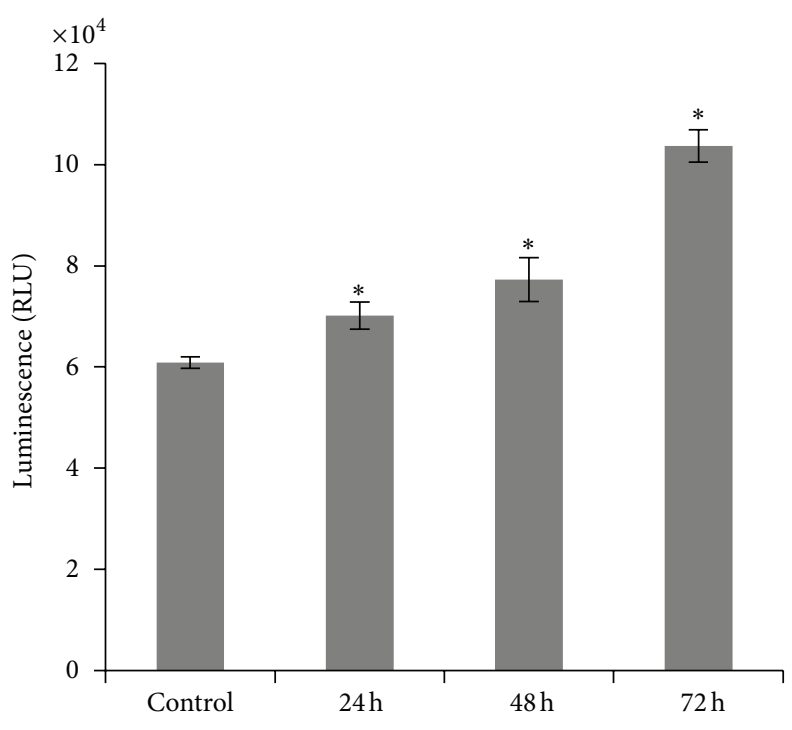

(c)

Figure 10: Relative luminescence expression of (a) caspase 3/7, (b) caspase 8, and (c) caspase 9 in the HepG2 cells treated with $11.43 \mu \mathrm{g} / \mathrm{mL}$ of ZER-HP $\beta$ CD inclusion complex for 24,48 , and $72 \mathrm{~h}$. Caspases $3 / 7,8$, and 9 were significantly increased compared to the control untreated cells. ${ }^{*}$ Indicates a significant difference $(P<0.05)$ compared with control.

increase during this period due to the treatment of ZER$\mathrm{HP} \beta \mathrm{CD}$ inclusion complex. It was reported previously that, in normal unstressed cells, Hsp-70 is expressed only at a very low level and nearly undetectable while in most human tumors, it is expressed at a very high level while adjusting to the unfavourable environmental conditions [49-51]. With the ability to suppress Hsp-70 in HepG2 cells, ZER-HP $\beta$ CD inclusion complex will be able to stop the growth of HepG2 cells which finally leads to apoptosis of the cells.

Procaspase activation and caspase activity need to be controlled in order to prevent overexpression of such proteins. In addition, the inhibition of apoptosis protein (IAPs), which acts as the modulator to directly control caspase activation, inhibits caspase 3, caspase 7, and caspase 9 activities. Among all IAPs identified, X-linked inhibitor of apoptosis protein (XIAP) is the most crucial in suppressing procaspase activation [52]. Hence, in order to induce cell death via apoptosis, protein suppression by XIAP must be crucially blocked. In this regard, the second mitochondria-derived activator of caspases (Smac)/DIABLO resumes the responsibility to suppress XIAP activity. As proapoptotic of Bcl-2 family induces the mitochondrial transmembrane potential $(\Delta \Psi \mathrm{m})$ changes, Smac/DIABLO protein is released from the mitochondria [53]. ZER-HP $\beta$ CD inclusion complex has shown the ability to induce XIAP inhibition through Smac protein activation in HepG2 cells and therefore allowing the cascade caspases 


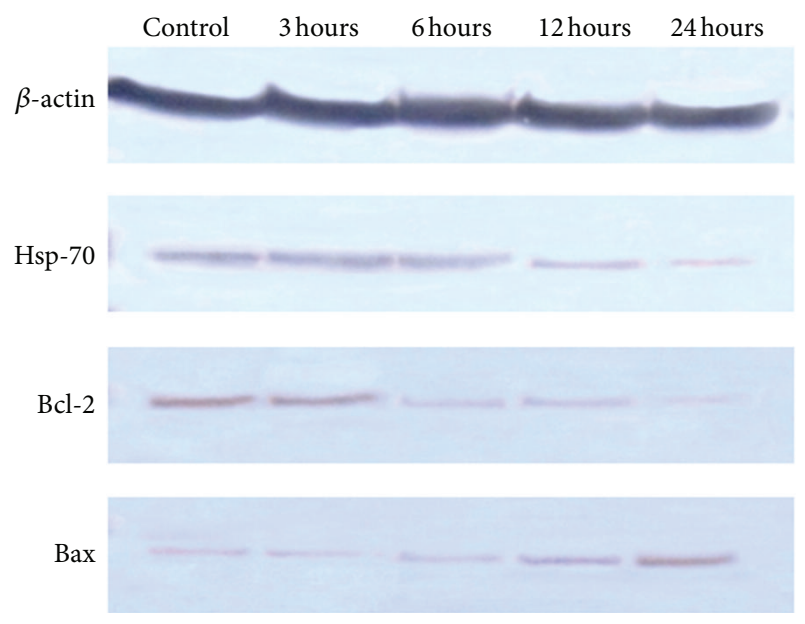

(a)

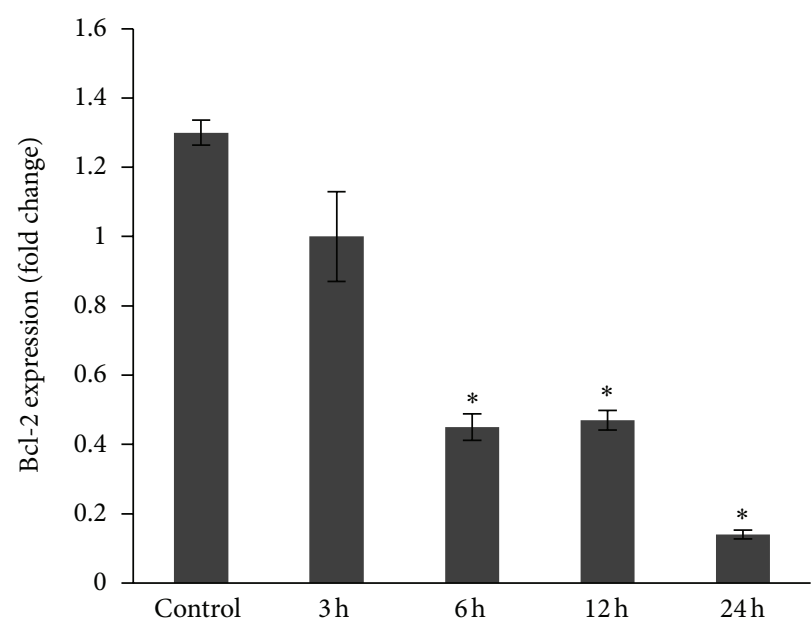

(c)

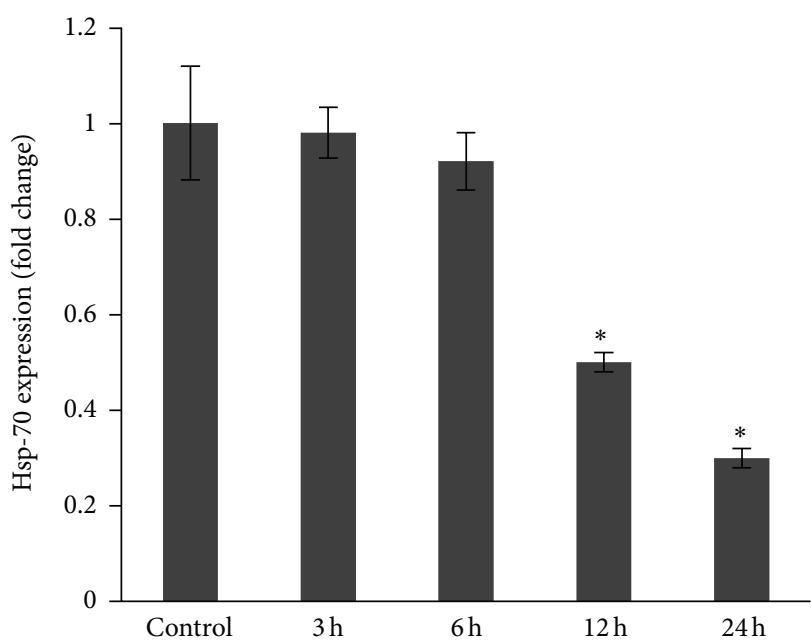

(b)

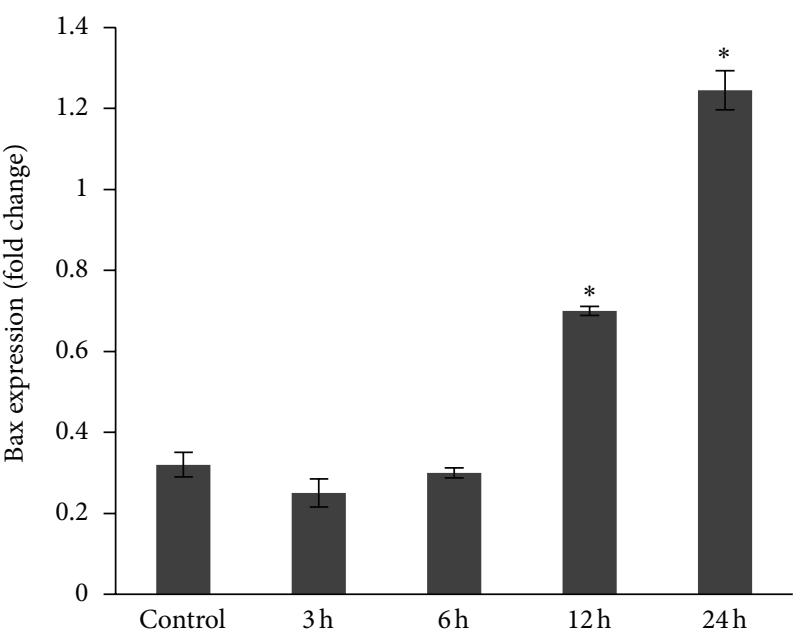

(d)

FIGURE 11: Western blot analysis on effect of ZER-HP $\beta$ CD inclusion complex on the levels of apoptosis regulatory proteins in HepG2 cells. Bax was upregulated while Bcl-2 in contrast downregulated in a time-dependent manner. Hsp-70 was also found to be depleted as time increases. The blot densities are expressed as folds of control. Detection of proteins was done by specific antibodies with $\beta$-actin as a loading control. Data are mean $\pm \mathrm{SD}(n=3) .{ }^{*} P<0.05$ versus control.

to be activated downstream which in turn triggered apoptosis induction.

\section{Conclusion}

Collectively, our current findings showed that the highly soluble ZER-HP $\beta$ CD inclusion complex possesses anticancer properties towards HepG2 cell line and the death receptor pathway may be involved in the induction of apoptosis. Our current finding can be extrapolated to postulate that caspase 8 's activation is indirectly involved as an interconnection between the extrinsic and intrinsic pathways. This ZER$\mathrm{HP} \beta \mathrm{CD}$ inclusion complex not only demonstrated antiproliferative effects towards HepG2 cells, but its high solubility in water provided the advantage to pursue the complex as a therapeutic drug candidate in humans.
Future in vivo studies are recommended prior to the use of the ZER-HP $\beta$ CD inclusion complex as an anticancer on hepatocarcinoma patients, and detailed toxicity studies of this complex are vital before pursuing human clinical trials.
Abbreviations
AO: $\quad$ Acridine orange
Apaf-1: Apoptotic protease-activating factor-1
Bax: $\quad$ Bcl-2 associated $\mathrm{X}$ protein
Bcl-2: $\quad$ B cell lymphoma 2
BID: $\quad$ BH3 interacting domain death agonist
DMSO: Dimethyl sulfoxide
FITC: Fluorescein isothiocyanate
HP $\beta C D$ : Hydroxypropyl- $\beta$-cyclodextrin
Hsp-70: Heat shock protein 70
$\mathrm{IC}_{50}$ : Half maximal inhibitory concentration 
MMP: Mitochondrial membrane potential

MTT: 3-(4,5-Dimethylthiazol-2-yl)-2,5diphenyltetrazolium

bromide

PI: $\quad$ Propidium iodide

PS: $\quad$ Phosphatidylserine

SMAC: Second mitochondria-derived activator of caspases

XIAP: X-linked inhibitor of apoptosis protein

ZER: Zerumbone

$\Delta \Psi \mathrm{m}$ : Mitochondrial transmembrane potential.

\section{Conflict of Interests}

The authors declare no conflict of interests.

\section{Acknowledgment}

The authors would like to express their utmost gratitude and appreciation to University Putra Malaysia for rendering financial support (RUGS) and University of Malaya (UM.C/625/1/HIR/151) for providing a grant to conduct this study.

\section{References}

[1] G. M. Cragg, D. G. I. Kingston, and D. Newman, Anticancer Agents from Natural Products, Taylor \& Francis Group, Boca Raton, Fla, USA, 2005.

[2] G. M. Cragg, D. J. Newman, and K. M. Snader, "Natural products in drug discovery and development," Journal of Natural Products, vol. 60, no. 1, pp. 52-60, 1997.

[3] O. Pancharoen, U. Prawat, and P. Tuntiwachwuttikul, "Phytochemistry of the zingiberaceae," Studies in Natural Products Chemistry, vol. 23, pp. 797-865, 2000.

[4] U. K. Ahmad, H. M. Sirat, M. M. Sanagi, and R. M. Smith, "Supercritical fluid extraction and capillary gas chromatography of the rhizomes of Z. Zerumbet," Journal of Microcolumn Separations, vol. 6, no. 1, pp. 27-32, 1994.

[5] N. I. Bhuiyan, J. U. Chowdhury, and J. Begum, "Chemical investigation of the leaf and rhizome essential oils of Zingiber zerumbet (L.) Smith from Bangladesh," Bangladesh Journal of Pharmacology, vol. 4, no. 1, pp. 9-12, 2009.

[6] Tushar, S. Basak, G. C. Sarma, and L. Rangan, "Ethnomedical uses of Zingiberaceous plants of Northeast India," Journal of Ethnopharmacology, vol. 132, no. 1, pp. 286-296, 2010.

[7] G. Kader, F. Nikkon, M. A. Rashid, and T. Yeasmin, "Antimicrobial activities of the rhizome extract of Zingiber zerumbet Linn," Asian Pacific Journal of Tropical Biomedicine, vol. 1, no. 5, pp. 409-412, 2011.

[8] N. J. Yob, S. M. Jofrry, M. M. R. M. M. Affandi, L. K. Teh, M. Z. Salleh, and Z. A. Zakaria, "Zingiber zerumbet (L.) Smith: a review of its ethnomedicinal, chemical, and pharmacological uses," Evidence-Based Complementary and Alternative Medicine, vol. 2011, Article ID 543216, 2011.

[9] J. Chane-Ming, R. Vera, and J. C. Chalchat, "Chemical composition of the essential oil from rhizomes, leaves and flowers of Zingiber zerumbet Smith from Reunion Island," Journal of Essential Oil Research, vol. 15, no. 3, pp. 202-205, 2003.

[10] A. Murakami, T. Tanaka, J. Y. Lee et al., "Zerumbone, a sesquiterpene in subtropical ginger, suppresses skin tumor initiation and promotion stages in ICR mice," International Journal of Cancer, vol. 110, no. 4, pp. 481-490, 2004.

[11] M. Kim, S. Miyamoto, Y. Yasui, T. Oyama, A. Murakami, and T. Tanaka, "Zerumbone, a tropical ginger sesquiterpene, inhibits colon and lung carcinogenesis in mice," International Journal of Cancer, vol. 124, no. 2, pp. 264-271, 2009.

[12] M. M. E. Taha, A. B. Abdul, R. Abdullah, T. A. T. Ibrahim, S. I. Abdelwahab, and S. Mohan, "Potential chemoprevention of diethylnitrosamine-initiated and 2-acetylaminofluorenepromoted hepatocarcinogenesis by zerumbone from the rhizomes of the subtropical ginger (Zingiber zerumbet)," ChemicoBiological Interactions, vol. 186, no. 3, pp. 295-305, 2010.

[13] S. I. Abdelwahab, A. B. Abdul, S. Mohan et al., "Zerumbone induces apoptosis in T-acute lymphoblastic leukemia cells," Leukemia Research, vol. 35, no. 2, pp. 268-271, 2011.

[14] S. I. Abdelwahab, A. B. Abdul, N. Devi et al., "Regression of cervical intraepithelial neoplasia by zerumbone in female $\mathrm{Balb} / \mathrm{c}$ mice prenatally exposed to diethylstilboestrol: involvement of mitochondria-regulated apoptosis," Experimental and Toxicologic Pathology, vol. 62, no. 5, pp. 461-469, 2010.

[15] E. E. M. Eid, A. B. Abdul, F. E. O. Suliman, M. A. Sukari, A. Rasedee, and S. S. Fatah, "Characterization of the inclusion complex of zerumbone with hydroxypropyl- $\beta$-cyclodextrin," Carbohydrate Polymers, vol. 83, no. 4, pp. 1707-1714, 2011.

[16] T. Mosmann, "Rapid colorimetric assay for cellular growth and survival: application to proliferation and cytotoxicity assays," Journal of Immunological Methods, vol. 65, no. 1-2, pp. 55-63, 1983.

[17] K. Mascotti, J. McCullough, and S. R. Burger, "HPC viability measurement: trypan blue versus acridine orange and propidium iodide," Transfusion, vol. 40, no. 6, pp. 693-696, 2000.

[18] S. C. Cheah, D. R. Appleton, S. T. Lee, M. L. Lam, A. H. A. Hadi, and M. R. Mustafa, "Panduratin a inhibits the growth of A549 cells through induction of apoptosis and inhibition of NFkappaB translocation," Molecules, vol. 16, no. 3, pp. 2583-2598, 2011.

[19] S. Mohan, S. I. Abdelwahab, B. Kamalidehghan et al., "Involvement of $\mathrm{NF}-\mathrm{kB}$ and $\mathrm{Bcl} 2 / \mathrm{Bax}$ signaling pathways in the apoptosis of MCF7 cells induced by a xanthone compound Pyranocycloartobiloxanthone A," Phytomedicine, vol. 19, no. 11, pp. 1007-1015, 2012.

[20] N. M. Isa, A. B. Abdul, S. I. Abdelwahab et al., "Boesenbergin A, a chalcone from Boesenbergia rotunda induces apoptosis via mitochondrial dysregulation and cytochrome c release in A549 cells in vitro: involvement of HSP70 and Bcl2/Bax signalling pathways," Journal of Functional Foods, vol. 5, no. 1, pp. 87-97, 2013.

[21] F. Firenzuoli and L. Gori, "Herbal medicine today: clinical and research issues," Evidence-Based Complementary and Alternative Medicine, vol. 4, supplement 1, pp. 37-40, 2007.

[22] A. H. Wyllie, J. F. R. Kerr, and A. R. Currie, "Cell death: the significance of apoptosis," International Review of Cytology, vol. 68 , pp. 251-306, 1980.

[23] S. Yasuhara, Y. Zhu, T. Matsui et al., "Comparison of comet assay, electron microscopy, and flow cytometry for detection of 
apoptosis," Journal of Histochemistry and Cytochemistry, vol. 51, no. 7, pp. 873-885, 2003.

[24] S. S. S. Alwi, M. Nallappan, and A. H. L. Pihie, "Zerumbone exerts antiproliferative activity via apoptosis on HepG2 cells," Malaysian Journal of Biochemistry and Molecular Biology, vol. 15, pp. 19-23, 2007.

[25] Y. Shounan, X. Feng, and P. J. O'Connell, “Apoptosis detection by annexin $\mathrm{V}$ binding: a novel method for the quantitation of cell-mediated cytotoxicity," Journal of Immunological Methods, vol. 217, no. 1-2, pp. 61-70, 1998.

[26] I. Vermes, C. Haanen, H. Steffens-Nakken, and C. Reutelingsperger, "A novel assay for apoptosis. Flow cytometric detection of phosphatidylserine expression on early apoptotic cells using fluorescein labelled Annexin V,' Journal of Immunological Methods, vol. 184, no. 1, pp. 39-51, 1995.

[27] S. J. Martin, C. P. M. Reutelingsperger, A. J. McGahon et al., "Early redistribution of plasma membrane phosphatidylserine is a general feature of apoptosis regardless of the initiating stimulus: inhibition by overexpression of Bcl-2 and Abl," Journal of Experimental Medicine, vol. 182, no. 5, pp. 1545-1556, 1995.

[28] S. Haldar, A. Basu, and C. M. Croce, "Bcl2 is the guardian of microtubule integrity," Cancer Research, vol. 57, no. 2, pp. 229233, 1997.

[29] S. I. Abdelwahab, A. B. Abdul, Z. N. M. Zain, and A. H. A. Hadi, "Zerumbone inhibits interleukin-6 and induces apoptosis and cell cycle arrest in ovarian and cervical cancer cells," International Immunology, vol. 12, no. 4, pp. 594-602, 2012.

[30] M. Xian, K. Ito, T. Nakazato et al., "Zerumbone, a bioactive sesquiterpene, induces G2/M cell cycle arrest and apoptosis in leukemia cells via a Fas- and mitochondria-mediated pathway," Cancer Science, vol. 98, no. 1, pp. 118-126, 2007.

[31] C. Kirana, G. H. McIntosh, I. R. Record, and G. P. Jones, "Antitumor activity of extract of Zingiber aromaticum and its bioactive sesquiterpenoid zerumbone," Nutrition and Cancer, vol. 45, no. 2, pp. 218-225, 2003.

[32] J. Nelson, E. Gibbons, K. R. Pickett et al., "Relationship between membrane permeability and specificity of human secretory phospholipase A2 isoforms during cell death," Biochimica et Biophysica Acta, vol. 1808, no. 7, pp. 1913-1920, 2011.

[33] V. P. Skulachev, "Why are mitochondria involved in apoptosis? Permeability transition pores and apoptosis as selective mechanisms to eliminate superoxide-producing mitochondria and cell," FEBS Letters, vol. 397, no. 1, pp. 7-10, 1996.

[34] J. P. Piret, T. Arnould, B. Fuks, P. Chatelain, J. Remacle, and C. Michiels, "Mitochondria permeability transition-dependent tert-butyl hydroperoxide-induced apoptosis in hepatoma HepG2 cells," Biochemical Pharmacology, vol. 67, no. 4, pp. 611-620, 2004.

[35] I. R. Indran, G. Tufo, S. Pervaiz, and C. Brenner, "Recent advances in apoptosis, mitochondria and drug resistance in cancer cells," Biochimica et Biophysica Acta, vol. 1807, no. 6, pp. 735-745, 2011.

[36] S. A. Sharifah Sakinah, S. Tri Handayani, and L. P. Azimahtol Hawariah, "Zerumbone induced apoptosis in liver cancer cells via modulation of Bax/ Bcl-2 ratio," Cancer Cell International, vol. 7, article 4, 2007.

[37] R. M. Kluck, E. Bossy-Wetzel, D. R. Green, and D. D. Newmeyer, "The release of cytochrome $\mathrm{c}$ from mitochondria: a primary site for Bcl- 2 regulation of apoptosis," Science, vol. 275, no. 5303, pp. 1132-1136, 1997.

[38] S. M. Srinivasula, M. Ahmad, T. Fernandes-Alnemri, G. Litwack, and E. S. Alnemri, "Molecular ordering of the Fasapoptotic pathway: the Fas/APO-1 protease Mch5 is a CrmAinhibitable protease that activates multiple Ced-3/ICE-like cysteine proteases," Proceedings of the National Academy of Sciences of the United States of America, vol. 93, no. 25, pp. 14486-14491, 1996.

[39] S. Wesselborg, I. H. Engels, E. Rossmann, M. Los, and K. Schulze-Osthoff, "Anticancer drugs induce caspase-8/FLICE activation and apoptosis in the absence of CD95 receptor/ligand interaction," Blood, vol. 93, no. 9, pp. 3053-3063, 1999.

[40] A. Gonçalves, D. Braguer, G. Carles, N. André, C. Prevôt, and C. Briand, "Caspase-8 activation independent of CD95/CD95$\mathrm{L}$ interaction during paclitaxel-induced apoptosis in human colon cancer cells (HT29-D4)," Biochemical Pharmacology, vol. 60, no. 11, pp. 1579-1584, 2000.

[41] M. C. Wei, T. Lindsten, V. K. Mootha et al., "tBID, a membranetargeted death ligand, oligomerizes BAK to release cytochrome c," Genes and Development, vol. 14, no. 16, pp. 2060-2071, 2000.

[42] H. Li, H. Zhu, C. J. Xu, and J. Yuan, "Cleavage of BID by caspase 8 mediates the mitochondrial damage in the Fas pathway of apoptosis," Cell, vol. 94, no. 4, pp. 491-501, 1998.

[43] S. J. Korsmeyer, M. C. Wei, M. Saito, S. Weiler, K. J. Oh, and P. H. Schlesinger, "Pro-apoptotic cascade activates BID, which oligomerizes BAK or BAX into pores that result in the release of cytochrome c," Cell Death and Differentiation, vol. 7, no. 12, pp. 1166-1173, 2000.

[44] T. Strobel, L. Swanson, S. Korsmeyer, and S. A. Cannistra, "BAX enhances paclitaxel-induced apoptosis through a p53independent pathway," Proceedings of the National Academy of Sciences of the United States of America, vol. 93, no. 24, pp. 14094-14099, 1996.

[45] G. J. Zhang, I. Kimijima, M. Onda et al., “Tamoxifen-induced apoptosis in breast cancer cells relates to down- regulation of bcl-2, but not bax and bcl-X(L), without alteration of p53 protein levels," Clinical Cancer Research, vol. 5, no. 10, pp. 29712977, 1999.

[46] M. Vayssade, L. Faridoni-Laurens, J. Bénard, and J. C. Ahomadegbe, "Expression of $p 53$-family members and associated target molecules in breast cancer cell lines in response to vincristine treatment," Biochemical Pharmacology, vol. 63, no. 9, pp. 1609-1617, 2002.

[47] M. B. Kastan, O. Onyekwere, D. Sidransky, B. Vogelstein, and R. W. Craig, "Participation of p53 protein in the cellular response to DNA damage," Cancer Research, vol. 51, no. 23, pp. 6304-6311, 1991.

[48] H. M. Beere, B. B. Wolf, K. Cain et al., "Heat-shock protein 70 inhibits apoptosis by preventing recruitment of procaspase- 9 to the Apaf-1 apoptosome," Nature Cell Biology, vol. 2, no. 8, pp. 469-475, 2000.

[49] C. Jolly and R. I. Morimoto, "Role of the heat shock response and molecular chaperones in oncogenesis and cell death," Journal of the National Cancer Institute, vol. 92, no. 19, pp. 1564$1572,2000$.

[50] L. Galluzzi, F. Giordanetto, and G. Kroemer, "Targeting HSP70 for cancer therapy," Molecular Cell, vol. 36, no. 2, pp. 176-177, 2009. 
[51] M. Rohde, M. Daugaard, M. H. Jensen, K. Helin, J. Nylandsted, and M. Jäättelä, "Members of the heat-shock protein 70 family promote cancer cell growth by distinct mechanisms," Genes and Development, vol. 19, no. 5, pp. 570-582, 2005.

[52] Y. Suzuki, Y. Imai, H. Nakayama, K. Takahashi, K. Takio, and R. Takahashi, "A serine protease, HtrA2, is released from the mitochondria and interacts with XIAP, inducing cell death," Molecular Cell, vol. 8, no. 3, pp. 613-621, 2001.

[53] M. MacFarlane, W. Merrison, S. B. Bratton, and G. M. Cohen, "Proteasome-mediated degradation of Smac during apoptosis: XIAP promotes Smac ubiquitination in vitro," The Journal of Biological Chemistry, vol. 277, no. 39, pp. 36611-36616, 2002. 


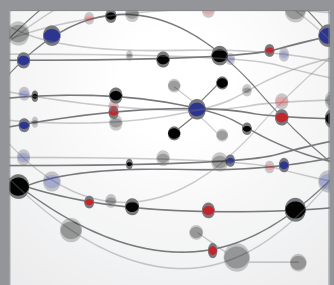

The Scientific World Journal
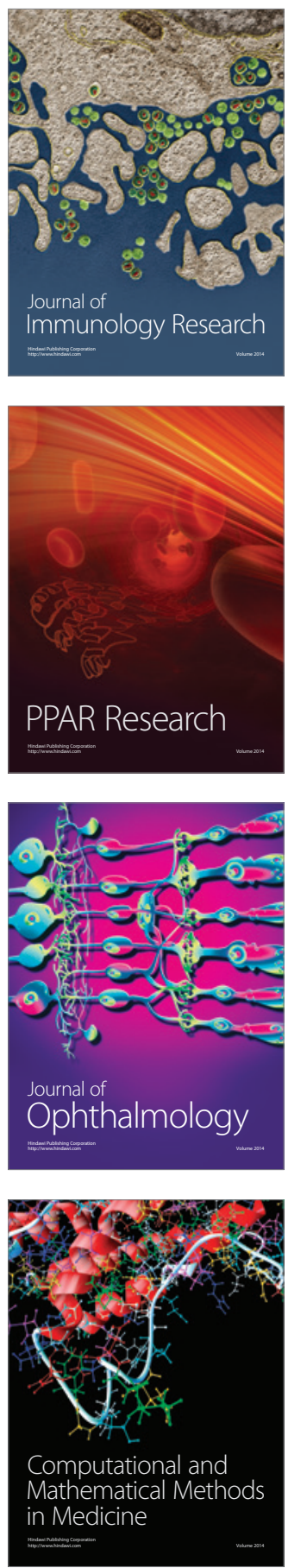

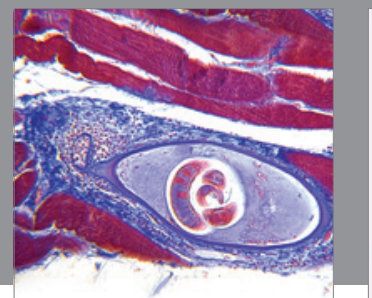

Gastroenterology

Research and Practice
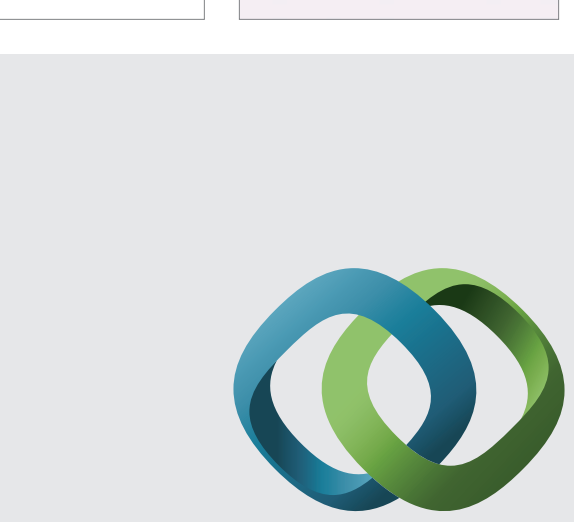

\section{Hindawi}

Submit your manuscripts at

http://www.hindawi.com
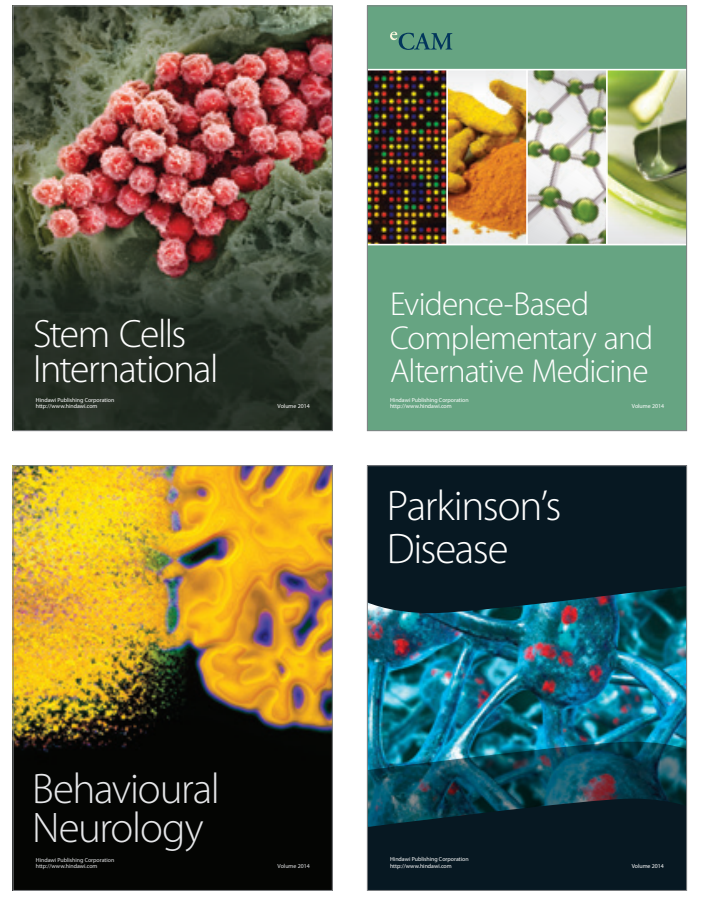
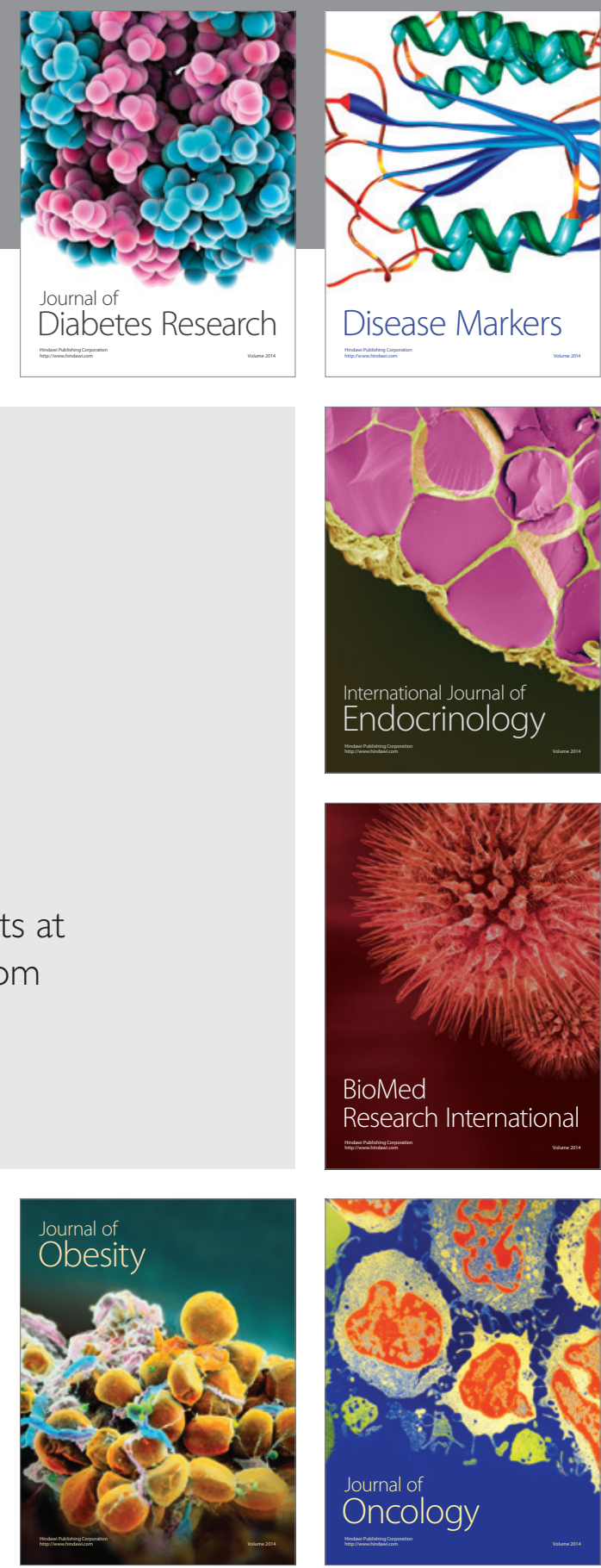

Disease Markers
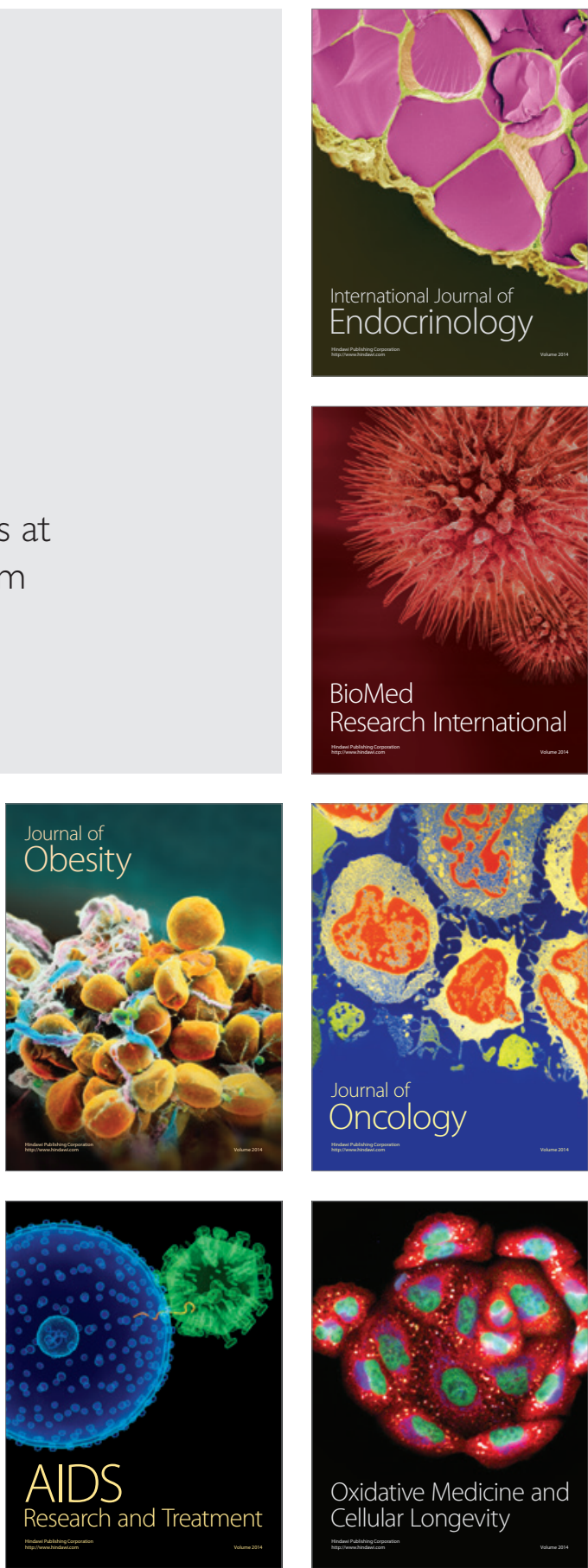